\title{
COMMENT
}

\section{TAX INCENTIVES AS STATE ACTION}

\section{INTRODUCTION}

The use of tax incentives ${ }^{1}$ as legislative devices to implement social and economic policy has recently become the subject of intense debate among economists, government agencies and legal scholars. This debate has focused primarily upon the comparative success and desirability of tax incentives as contrasted with other forms of government assistance designed to effectuate similar policy goals. ${ }^{2}$ Two major issues have been most frequently argued: whether tax incentives can be considered

1 In the course of the debate over the use of tax provisions to effectuate public policy, certain key terms have taken on rather specific definitions. This Comment will adhere essentially to the definitions of "tax expenditure" and "tax incentive" set out by Surrey, Tax Incentives as a Device for Implementing Government Policy: A Comparison with Direct Govermment Expenditures, 83 HARv. L. REv. 705, 706-07 (1970) [hereinafter cited as Tax Incentives]:

those special provisions of the federal income tax system which represent government expenditures made through that system to achieve various social and economic objectives. These special provisions provide deductions, credits, exclusions, exemptions, deferrals, and preferential rates, and serve ends similar in nature to those served by direct government expenditures or loan programs ... (and thus they serve ends) other than measurement of net income under an income tax.

The phrase "and other than the measurement of property value under a property tax" should be added to the end of the definition. Tax expenditures discussed in this Comment are intended to include both income and property tax provisions enacted by local, state or federal governments. The meaning of "tax incentive" will be: "a tax expenditure which induces certain activities or behavior in response to the monetary benefit available." Id. 711 .

${ }_{2}^{2}$ It should be noted at the outset that this Comment does not advocate any particular position in this dispute, but is concerned strictly with the constitutionality of tax incentives. However, the debate has generated a vast amount of valuable information which is extremely useful in illuminating the constitutional issue. For outstanding work done recently in the field, see C. Kahn, Personal Deductions in the Federal Income Tax (1960); Tax Institute of America, Tax Impacts on Philanthropy (1972); Tax INSTITUTE OF AMERICA, TAX INCENTIVES (1971); Bittker, $A$ "Comprehensive Tax Base" as a Goal of Income Tax Reform, 80 Harv. L. REv. 925 (1967); Bittker, Accounting for Federal "Tax Subsidies" in the National Budget, 22 NaT. TAX J. 244 (1969); Bittker, Churches, Taxes and the Constitution, 78 Y ALE L.J. 1285 (1969); Blum, Federal Income Tax Reform-Twenty Questions, 41 TAXES 672 (1963); Kurtz, Tax Incentives: Their Use and Misuse, 20 U. So. CaL. 1968 TAX INST. 1; MCDaniel, Alternatives to Utilization of the Federal Income Tax System to Meet Social Problems, 11 B.C. IND. \& CoM. L. REv. 867 (1970); McDaniel, Federal Matching Grants for Charitable Contributions: A Substitute for the Income Tax Deduction, 27 TAX L. Rev. 377 (1972); McDaniel \& Kaplinsky, The Use of the Federal Income Tax System to Combat Air and Water Pollution: A Case Study in Tax Expenditures, 12 B.C. IND. \& CoM. L. REv. 351 (1971); Rabin, Charitable Trusts and Charitable Deductions, 41 N.Y.U.L. Rev. 912 (1966); Stone, Federal Tax Support of Charities and Other Exempt Organizations: The Need for a National Policy, 20 U. So. CAL. 1968 TAX InST. 27; Surrey, Federal Income Tax Reforms: The Varied Approaches Necessary to Replace Tax Expenditures with Direct Governmental Assistance, 84 Harv. L. Rev. 352 (1970); Tax Incentives, supra note 1; Taussig, Economic Aspects of the Personal Income Tax Treatment of Charitable Contributions, 20 NAT. TAX J. 1 (1967); Warren, Krattenmaker \& Snyder, Property Tax Exemptions for Charitable, Educational, Religious and Governmental Institutions in Connecticut, 4 CoNN. L. REv. 181 (1971); Wolfman, Federal Tax Policy and the Support of Science, 114 U. PA. L. REv. 171 (1965); Note, Federal Tax Benefits to Segregated Private Schools, 68 Colum. L. Rev. 922 (1968). 
economically equivalent to government expenditures and other subsidies; and what should be the degree of public and legislative review of tax incentives as compared to that accorded alternative forms of government assistance. Although criticism of tax incentives has been diverse and far-reaching, ${ }^{3}$ the debate has seldom reached the question whether tax incentives are constitutionally equivalent to government expenditures and other subsidies, requiring the same degree of constitutional review as has traditionally been afforded these other forms of government assistance. ${ }^{4}$

The recent case of $M c$ Glotten $v$. Connally ${ }^{5}$ dealt directly with the constitutional issue. It evoked in response one of the first scholarly attempts ${ }^{6}$ to meet the question, an article coauthored by Professor Boris I. Bittker and Kenneth M. Kaufman, ${ }^{7}$ in which the authors severely criticize the McGlotten opinion of Judge Bazelon.

In McGlotten, the Secretary of the Treasury was enjoined from granting tax exemptions ${ }^{8}$ to racially discriminatory fraternal organizations, and from permitting donors to those organiza-

${ }^{3}$ Some have suggested that tax incentives are an undesirable form of government assistance because they are insulated from the extensive public and legislative examination ordinarily encountered by grants, loans and interest subsidies. In the absence of such regular legislative review, it is argued, tax incentives tend to outlive their usefulness and survive in the tax codes as concealed subsidies. Another criticism of tax incentives is that once they have been enacted, they enjoy a presumption of legislative approval. If a particular tax incentive is to be reduced or eliminated, the burden is on its opponents to persuade the legislature, say the critics. Other commentators have claimed that government control over activities supported by tax incentives is inadequate, and that the cost of tax incentives to the government is unpredictable and frequently openended. See sources cited note 2 supra. One tax incentive in particular, the charitable deduction, has been criticized for favoring taxpayers in the higher income brackets, and thus violating two fundamental objectives of income taxation-equity and progressivity. See Vickrey, One Economist's View of Philanthropy, in Philanthropy and Public Policy 31 (F. Dickinson ed. 1962). Also, for an example of extraordinary recommendations by a representative of a charitable organization, see the report of Alan Pifer, President of the Carnegie Corporation of New York: Pifer, Revitalizing the Charitable Deduction, in 1972 ANNUAL REPORT OF The Carnegie Corporation of New York [characterizing the federal income tax deduction as a provision that drastically needs to be "more democratic"]

4 A most notable exception is the commentary dealing with the constitutionality of tax incentives granted to private segregated schools. See, e.g., U.S. Comm'N on CIVIL RIGHTs, Legal Implications of Federal Tax Benefits to Racially Segregated Private Schools, in Southern School Desegregation, 1966-67, at 142 (1967); Silberblatt, Denial of Tax Exempt Status to Southern Segregated Academies, 6 HARv. Crv. Rights-Crv. Lib. L. Rev. 179 (1970); Spratt, Federal Tax Exemption for Private Segregated Schools: The Crumbling Foundation, 12 WM. \& MARY L. Rev. 1 (1970); Note, Federal Tax Benefits to Segregated Private Schools, 68 Colum. L. REv. 922 (1968); Note, The Validity of Tax Benefits to Private Segregated Schools, 68 Mich. L. Rev. 1410 (1970). Many of these articles were written in response to Green v. Connally, 330 F. Supp. 1150 (D.D.C.), aff'd mem. sub nom. Coit v. Green, 404 U.S. 997 (1971), and Green v. Kennedy, 309 F. Supp. 1127 (D.D.C.), appeal dismissed sub nom. Cannon v. Green, 398 U.S. 956 (1970), sub nom. Coit v. Green, 400 U.S. 986 (1971).

${ }^{5} 338$ F. Supp. 448 (D.D.C. 1972).

${ }^{6}$ For other commentaries on the fraternal order cases see Note, The Internal Revenue Code and Racial Discrimination, 72 Colum. L. Rev. 1215 (1972); Note, Granting of Tax Benefits to Discriminatory Fraternal Orders is a Violation of the Equal Protection Aspect of the Fifth Amendment, 18 VILL. L. REv. 93 (1972).

'Bittker \& Kaufman, Taxes and Civil Rights: "Constitutionalizing" the Internal Revenue Code, 82 YALE L.J. 51 (1972) [hereinafter cited as Taxes and Civil Rights].

${ }^{8}$ INT. REV. CODE OF 1954, § 501 (c)(8). 
tions to deduct their contributions. ${ }^{9}$ One of the three independent grounds for the injunctive relief granted was that such tax incentives violate the equal protection clause, ${ }^{10}$ because they constitute significant government subsidies supporting and encouraging racial discrimination. McGlotten is one of several recent decisions in the lower federal courts ${ }^{11}$ which have held that the government subsidies resulting from the granting of federal or state tax incentives to private organizations can be sufficient to transform the otherwise private discrimination practiced by those organizations into "state action" subject to the prohibitions of the equal protection clause. Prior to these cases, direct grants from the state and federal governments had been virtually the only form of government subsidy to discriminatory private organizations which had been invalidated by the courts.

Tax incentives have seldom been singled out to be tested as a form of government subsidy to private discrimination, although courts have examined the constitutionality of tax incentives as one element in a composite pattern of government involvement with private discrimination. ${ }^{12} \mathrm{McGlotten}$ and its companion cases are therefore significant for having introduced a revolutionary concept into constitutional law: that tax incentives, like other forms of government assistance, are subject to the requirements of the Constitution, and may not be utilized to

${ }^{9} I d . \S 170(\mathrm{c})(4)$.

${ }^{10}$ The fifth amendment's due process clause has been held to impose a duty upon the federal government similar to that required of the states by the equal protection clause of the fourteenth amendment. See Frontiero v. Richardson, 411 U.S. 677, 680 n.5 (1973) \& sources cited; Bolling v. Sharpe, 347 U.S. 497, 500 (1954); Note, Sex Discrimination and Equal Protection: Do We Need a Constitutional Amendment?, 84 HARV. L. REv. 1499, 1502 n.24 (1971).

${ }^{11}$ See, e.g., Jackson v. Statler Foundation, No. 73-1543 (2d Cir. Dec. 4, 1973); Falkenstein v. Department of Revenue, 350 F. Supp. 887 (D. Ore. 1972), appeal dismissed, 93 S. Ct. 907 (1973); Pitts v. Department of Revenue, 333 F. Supp. 662 (E.D. Wis. 1971). Cf. Junior Chamber of Commerce v. United States Jaycees, No. 73-C-66 (N.D. Okla., Jun. 26, 1973); McCoy v. Shultz, Civ. No. 1580-72 (D.D.C., Feb. 13, 1973).

${ }_{12}$ The question whether tax incentives are capable of activating the equal protection clause was first resolved in Pitts v. Department of Revenue, 333 F. Supp. 662 (E.D. Wis. 1971). Prior to this decision, the mere granting of tax incentives had been held insufficient to violate the first amendment establishment clause in Walz v. Tax Commission, 397 U.S. 664 (1969), and inadequate to activate the due process clause of the fourteenth amendment in Browns v. Mitchell, 409 F.2d 593 (10th Cir. 1969). There have been numerous cases holding that tax incentives, as part of an overall pattern of government involvement, do not suffice to activate constitutional restrictions. See Blackburn v. Fisk University, 443 F.2d 121 (6th Cir. 1971); Chicago Joint Board, Amalgamated Clothing Workers v. Chicago Tribune Co., 435 F.2d 470 (7th Cir. 1970), cert. denied, 402 U.S. 973 (1971); Braden v. University of Pittsburgh, 343 F. Supp. 836 (W.D. Pa. 1972), vacated $\xi^{2}$ remanded, 447 F.2d 1 (3d Cir. 1973); Bright v. Isenbarger, 314 F. Supp. 1382 (N.D. Ind. 1970), aff'd, 445 F.2d 412 (7th Cir. 1971); Dorsey v. Stuyvesant Town Corp., 299 N.Y. 512, 87 N.E. 541 (1949).

There have also been cases holding tax incentives part of a composite scheme of government involvement with private activity sufficient to subject that activity to constitutional scrutiny. See Evans v. Newton, 382 U.S. 296 (1966); Burton v. Wilmington Parking Authority, 365 U.S. 715 (1961); Eaton v. Grubbs, 329 F.2d 710 (4th Cir. 1964); Holmes v. Silver Cross Hospital, 340 F. Supp. 125 (N.D. Ill. 1972); Pennsylvania v. Brown, 270 F. Supp. 782 (E.D. Pa. 1967), aff'd mem., 392 F.2d 120 (3d Cir. 1968), cert. denied, 391 U.S. 921 (1968); Greisman v. Newcomb Hospital, 40 N.J. 389, 192 A.2d 817 (I963). 
support and encourage private discrimination in violation of the equal protection clause.

In Taxes and Civil Rights, Bittker and Kaufman express strong reservations regarding this novel constitutional principle, and offer a five point criticism of $M c$ Glotten. First, they contend that $M c$ Glotten failed to apply properly the approach formulated by the Supreme Court in Burton v. Wilmington Parking Authority ${ }^{13}$ to guide lower federal courts in making case-by-case determinations whether a particular government involvement with private discrimination is so substantial as to constitute state action under the fourteenth amendment: "Only by sifting facts and weighing circumstances can the nonobvious involvement of the State in private conduct be attributed its true significance."14 Bittker and Kaufman contend that the McGlotten analysis would apply equally to all fraternal orders without regard to their size, the extent or location of their facilities, the nature and scope of their activities, and other differentiating characteristics. This inflexibility, they argue, is incompatible with the language and spirit of Burton, which encouraged courts to consider a wide range of factors in resolving the issue of state action.

Second, Bittker and Kaufman attack what they perceive to be the "core of the constitutional holding in McGlotten"15: the assumption that tax incentives are capable of being distinguished from tax provisions which serve to define income, and that these tax incentives should be considered government subsidies. They deny that it is possible to arrive at any universally acceptable ideal concept of income, denouncing the Haig-Simons definition ${ }^{16}$ generally accepted by those who believe that tax incentives can be distinguished from income-defining tax provisions. They suggest also that if tax incentives can be identified, the exemption enjoyed by fraternal orders might not be a tax incentive, but merely a provision intended to simplify and reduce the cost of administering the Internal Revenue Code. Congress might have concluded that computing and recording the income of fraternal organizations would be too burdensome and costly to warrant taxing them. Lastly, Bittker and Kaufman assert that the McGlotten court was inconsistent in applying its own theory, since it failed to treat the social club exemption of section $501(\mathrm{c})(7)$ identically with the fraternal order exemption of section $501(\mathrm{c})(8)$. This inconsistency, they claim, undermines the validity of the $M c G l o t t e n$ tax subsidy theory.

The third criticism of McGlotten presented by Bittker and Kaufman questions the wisdom of the "chosen instrumentality

13365 U.S. 715 (1961).

${ }^{14}$ Id. at 722 .

15 Taxes and Civil Rights, supra note 7, at 62.

${ }^{16}$ See note 190 infra \& accompanying text. 
theory."17 According to Bittker and Kaufman, under McGlotten only those tax incentives aimed at "particular organizations with particular purposes"18 will convert the otherwise private discrimination practiced by their recipients into unlawful state action; across-the-board ${ }^{19}$ tax incentives create no constitutional obligations for their recipients. Bittker and Kaufman attempt to demonstrate the arbitrariness of this distinction by applying the theory to section $167(\mathrm{k})$ of the Internal Revenue Code, an across-the-board provision granting a deduction for the rehabilitation of low-income rental housing. They argue that section $167(\mathrm{k})$ is unobjectionable under the McGlotten test, yet is more obviously an incentive to private activity than section $170(\mathrm{c})(4)$; therefore the theory is arbitrary.

Fourth, the authors of Taxes and Civil Rights assert that the $M c G l o t t e n$ opinion erroneously characterizes the role of tax incentives in private discrimination as one of approval. They contend that the government's role is actually far less active. ${ }^{20}$ And finally, Bittker and Kaufman contend that tax incentives are so widespread that almost every private activity in the United States would be subjected to constitutional restrictions if tax incentives were characterized as significant government involvement in violation of the fourteenth amendment.

Many of the points raised in Taxes and Civil Rights are sound and persuasive. However, it is quite difficult to unite them in a coherent conclusion regarding the role of the constitution in granting tax incentives. The article concludes on a cautionary note:

If full sway is given to the McGlotten theory that tax allowances are equivalent to direct grants of public funds and hence impose constitutional obligations on the recipient, no one will be immune .... [T] he tax subsidy theory-whether in an unadulterated form or as watered down by McGlotten-turns on technical niceties of tax law that are unrelated to the impact of the organization's behavior on the persons excluded by its membership rules or other restrictive practices. It would, therefore, be a mistake to use this theory to "constitutionalize" the Internal Revenue Code. ${ }^{21}$

is Taxes and Civil Rights, supra notc 7, at 73 .

$18338 \mathrm{~F}$. Supp. at 459.

19 Id.

${ }^{20}$ Bittker and Kaufman contend that the government's role is less active than approval because: (1) a ruling or determination letter from the Internal Revenue Service is not a prerequisite to deductibility of contributions, (2) Service rulings and determination letters are furnished to several types of taxpayers besides nonprofit organizations, and (3) no $\$ 501(c)(7)$ fraternal orders are listed in the Treasury's Cumulative List of Exempt Organizations. They conclude that granting tax incentives should not be considered approval for purposes of constitutional analysis.

${ }^{21}$ Taxes and Civil Rights, supra note 7, at 86-87. 
Several meanings might be inferred from Taxes and Civil Rights. The authors might have been warning against blind acceptance of the theory that tax incentives are functionally equivalent to other means of government assistance designed to stimulate private activity in furtherance of government policies. Acceptance of such a theory will necessarily lead to the conclusion, they believe, that all tax incentives will impose constitutional restrictions upon their recipients, ignoring the possibility that under the flexible Burton approach some tax incentives-as well as some direct grants, loans and interest subsidies-will be deemed too insignificant to activate constitutional restrictions.

Alternatively, perhaps Bittker and Kaufman intended to deny that the Internal Revenue Code can be "constitutionalized," because the flaws which they perceive in the tax subsidy theory are so severe that tax incentives can never serve to transform private discrimination into unconstitutional state action. This second conclusion is equally unacceptable. Legislatures have demonstrated the ease with which alternative programs can be tailored to accomplish exactly the same objectives-one employing tax incentives, the other direct grants. ${ }^{22}$ In such a situation, there is no logical reason to find state action in one program, but not in the other. In fact, such a result would encourage legislatures to employ tax provisions to accomplish objectives known to be impermissible if pursued under a direct expenditure scheme. Governments at the federal, state and local levels could continue allocating billions of dollars ${ }^{23}$ annually in tax incentives without any constitutional review. A more acceptable conclusion, which Bittker and Kaufman may have intended, is that the Internal Revenue Code is capable of being "constitutionalized," but that the court in McGlotten simply failed to devise an adequate analytical framework within which to approach the concept of state action.

This Comment proposes such an analytical framework, which draws heavily from both McGlotten and Taxes and Civil Rights. This proposed framework is an attempt to devise a comprehensive scheme for the application of constitutional restrictions to all forms of government involvement with private conduct, including tax incentives. By contrasting the divergent guidelines which have been evolved with respect to these clauses, an analytical framework can be formulated that is capable of governing the application of constitutional restrictions to most government involvement with private conduct.

In Section II of the Comment, the economic nature of tax

22 See text accompanying notes 71-75 infra.

23 The federal government alone allocates over $\$ 47$ billion annually in tax incentives. The aggregate amount of tax incentives granted annually by state and local governments has yet to be measured. 
benefits ${ }^{24}$ is examined and compared with the economic nature of direct government expenditures; it is concluded that tax benefits are functional equivalents of direct expenditures. Section III outlines an analytical framework to govern the application of constitutional restrictions to tax incentives. The concluding section questions whether tax incentives ${ }^{25}$ can be logically and meaningfully isolated from other tax benefits. It is concluded that tax incentives should be defined to be those tax provisions which are not intended to define income or property value. Finally, the consitutional analysis developed in the preceding sections is applied to particular tax incentives to discern whether their operation should activate constitutional restrictions.

\section{The Economic Nature of Tax Benefits ${ }^{26}$ - Functional Equivalence to Direct EXPENDITURES}

From a strictly economic perspective, tax benefits can be viewed as functional equivalents of direct expenditures of government funds. This section of the Comment will compare tax benefits with direct government expenditures solely in terms of functional economic impact. A discussion of the constitutional impact of tax benefits will follow in Section IV.

The allocation of government expenditures and the collection of taxes by the state ${ }^{27}$ are interdependent halves of a single fiscal process. Revenue is gathered in the form of taxes and distributed through a variety of government expenditures. There is no significant difference in economic impact between a legislative decision that a particular entity should receive a direct government grant of a certain amount, and one that it should be relieved of its otherwise payable tax burden by that amount. This proposition is accurate for all three basic varieties of tax benefits-exemptions, deductions and credits.

${ }^{24}$ For the definition of "tax benefit" used in this Comment, see note 26 infra.

${ }^{25}$ Compare the definition of "tax incentive," note 1 supra, with the definition of tax benefit, note 26 infra. The distinction between the two, which is essential to the central argument presented in this Comment, is developed more fully in Section IV infra.

${ }_{26}$ The term "tax benefit" used here includes every tax provision which provides taxpayers with advantageous tax treatment. As used in this Comment, the term is broad enough to include all exemptions, deductions and credits, including those which will later be seen to be "true" income or property value defining provisions. In Taxes and Civil Rights, Bittker and Kaufman use the term "tax allowances" similarly, to describe a class of tax provisions broad enough to include both tax subsidies and true income defining provisions, as they were distinguished in McGlotten. Taxes and Civil Rights, supra note 7, at 62.

Since this section compares only the functional economic impact of tax benefits with that of direct expenditures, a discussion of legislative objectives and other factors germane to a determination of the constitutionality of tax benefits is not appropriate here. These issues will be discussed in Section IV infra.

27 The term "state" as used herein includes federal, state and local governments. The taxes discussed include property, income, gift and estate taxes collected at any of these levels of government. 
By granting a tax exemption to a particular entity, the legislature relieves that entity of the taxpaying obligation borne by others. The legislature could accomplish an equivalent fiscal result by including the entity within the tax base, taxing it directly and then granting it a subsidy equal to the tax it paid; this direct expenditure alternative differs from the tax exemption only in that both the tax base and total governmental expenditures have increased by the amount of the tax paid by the entity.

A deduction also produces an economic result similar to that produced by a direct expenditure. The government, by allowing individual taxpayers to decrease their taxable income through deductions, permits them to allocate funds which would otherwise be collected as tax. The recipient of these funds thus becomes the beneficiary of government largesse. This scheme of private allocation of public resources has frequently been characterized as a "matching grant" system, authorizing private taxpayers to channel funds which are partially earmarked for government collection.

Tax credits are the tax benefit structurally most similar to direct government expenditures. A tax credit is a reimbursement credited to a taxpayer by the government, reducing the total tax paid by that taxpayer. Tax credits are more closely analogous to direct government expenditures than tax deductions because the full amount of a credit, but only a percentage of a deduction, constitutes government funds.

Endorsements of the theory that tax benefits are functionally equivalent to direct government spending have come from most scholars and theorists who have dealt with the issue, ${ }^{28}$ as well as from various levels of the executive and legislative branches of government. Proponents include state legislatures; ${ }^{29}$

${ }^{28}$ See, e.g., sources cited note 2 supra; J. Maxwell, Financing State and Local GovernMENT 152 (1965); Aaron, Federal Encouragement of Private Giving, in TAX Institute of America, Tax Impacts on Philanthropy, 210, 211 (1972); Korbel, Do Federal Income Tax Laws Involve an "Establishment of Religion"?, 53 A.B.A.J. 1018, 1019 (1967); McDaniel, Discussion of Support of Private Philanthropy Through Federal Income Tax Laws, in Tax Institute of AMERICA, Tax Impacts on Philanthropy, 220, 227 (1972); Taubman \& Rasche, The Income Tax and Real Estate Investment, in TAx INSTITUTE of AMERICA, TAX InCENTIVES, 113 (1971); Vickrey, supra note 3, at 33; Note, The Internal Revenue Code and Racial Discrimination, 72 Colum. L. REv. 1215, 1219 (1972).

${ }_{29}$ A joint committee of the New York Legislature wrote a report which is cited in Advisory Commission on Intergovernmental Relations, The Role of the STATE in Strengthening the Property Tax 85 (1963): "Tax exemption does give a subsidy, but the trouble is that it is a blind subsidy, controlled by accident. And it is, moreover, a compulsory subsidy which cannot be reviewed and fixed by those who pay it as sound finance demands."

Temporary Commission to Study the Tax Laws of the State and to Make Recommendations Concerning Their Revision, Report 242 (Conn. 1934) is cited in Warren, Krattenmaker \& Snyder, Property Tax Exemptions for Charitable, Educational, Religious and Governmental Instilutions in Connecticut, 4 CoNs. L. Rev. 181, 306 (1971):

Exemption from taxation is a bounty or subsidy. There would be less difficulty if all exemptions were abolished and public assistance to worthy activities were 
the Internal Revenue Service ${ }^{30}$ and other sources within the Treasury Department, including an Assistant Secretary of the Treasury for Tax Policy ${ }^{31}$ and a Secretary of the Treasury; ${ }^{32}$ congressional committees; $;^{33}$ a presidential commission; ${ }^{34}$ a prominent congressman; ${ }^{35}$ and a former President. ${ }^{36}$ There has been

made by the General Assembly in the form of outright grants, bounties or subsidies. But because of tradition, the vested interests attaching to existing exemptions and prevailing public sentiment, such a solution of the problem is at present only of academic interest.

${ }^{30} \mathrm{~A}$ former assistant chief counsel of the Internal Revenue Service described the economic function of a tax exemption as follows:

Where the object of an exemption, which here is income, is of a character which is subject to tax, the effect is to save the beneficiaries of the exemption from tax at the expense of individuals who are taxed. From the standpoint of people and their principles of government, such inequality is not equity in taxation. Moreover, it differs only in method from a disbursement of government funds.

Reiling, What is a Charitable Organization?, 44 A.B.A.J. 525, 529, 595 (1958) (emphasis added).

${ }^{31}$ In a speech given in 1967, Stanley Surrey, then Assistant Secretary of the Treasury for Tax Policy, suggested that

through deliberate departures from accepted concepts of net income and through various special exemptions, deductions and credits, our tax system does operate to affect the private economy in ways that are usually accomplished by expenditures-in effect to produce an expenditure system described in tax language.

Surrey \& Hellmuth, The Tax Expenditure Budget-Response to Professor Bittker, 22 NAT. TAX J. 528 (1969).

${ }_{32}$ Subsequent to the Surrey speech just cited, the Treasury Department included a report on tax expenditures in the Fiscal 1968 Report of the Secretary of the Treasury. Surrey \& Hellmuth, supra note 31 , at 529. Secretary Joseph Barr presented the study before the Joint Economic Committee in January of 1969 , including in his remarks the following statement: "Through special provisions in the tax system, similar in effect to appropriations, we are now making available huge sums of money to various functional sectors of the budget." Hearings on the 1969 Economic Report of the President Before the Joint Economic Committee, 91 st Cong;, 1st Sess. 8 (1969). The Treasury repeated this tax expenditure analysis the following year, and the Joint Economic Committee has subsequently urged that the tax expenditure approach be employed in drawing up the Federal budget. Surrey, Federal Income Tax Reform: The Varied Approaches Necessary to Replace Tax Expenditures With Direct Governmental Assistance, 84 HARv. L. REv. 352, 355 (1970).

Finally, the staffs of the Treasury Department and the Joint Committee on Internal Revenue Taxation have prepared a report for the House Committee on Ways and Means entitled Estimates of Federal Tax Expenditures, which covers the fiscal year 1971.

${ }^{33}$ The Joint Committee conducted a study of federal tax policy for economic growth and stability, in which Walter Blum pointed out the disadvantages of a "subsidy by way of tax preference." See Bittker, Accounting for Federal "Tax Subsidies" in the National Budget, 22 NaT. TAx J. 244 (1969). Walter W. Heller, testifying before the House Committee on Ways and Means, discussed the hidden nature of government spending through tax incentives:

The back door to government subsidies marked "tax relief is easier to push open than the front door marked "expenditures" or the side door marked "loans, guarantees, and insurance." ... [H]ere is a whole catacombs of Government benefits which are largely hidden from public view, let alone, periodic review.

Heller, Some Observations on the Role and Reform of the Federal Income Tax, in House Commirtee on Ways and Means, Tax Revision Compendium 181, 190 (1959).

${ }^{34}$ In a study on property taxes, the President's Advisory Commission on Intergovernmental Relations concluded that the exemption for nonprofit religious, charitable and educational institutions "adds up to a large, concealed government subsidy for numerous classes of nonprofit institutions and organizations .... No nationwide data are available, however, on the value of these indirect subsidies." ADvisory CoMmission on Intergovernmental Relations, The Role of the States in Strengthening the PropertyTax 84 (1963).

${ }^{35}$ Congressman Wilbur Mills has referred to special tax relief as "back-door spending" and "indirect subsidy." 113 Cong. Rec. 16,890 (daily ed., Dec. 13, 1967), ciled in 22 NAT. TAX J. 244, 245 (1969).

${ }^{36}$ Economic Report of The President 18 (Jan. 1966), cited in Stone, Federal Tax 
discussion in the courts as well of the issue of the functional economic equivalence of tax benefits and direct expenditures. ${ }^{37}$ Most lower federal courts which have explicitly considered the functional equivalence theory have adopted it. ${ }^{38}$ In Green $v$. Kennedy, ${ }^{39}$ the Internal Revenue Service was enjoined from granting tax exempt status to private schools which were racially segregated. The impact of section 170 of the Internal Revenue Code was described in Green as a "matching grant." 40 In Green $v$. Connally, ${ }^{41}$ tax benefits to the same schools were analyzed in the following terms: "[T]ax exemptions and deductions certainly constitute a Federal Government benefit and support. While that support is indirect, and is in the nature of a matching grant rather than an unconditional grant . . ."42 The court in Pitts $v$. Department of Revenue ${ }^{43}$ enjoined the granting of Wisconsin state income and property tax exemptions to racially discriminatory fraternal organizations. These tax benefits were viewed as providing those organizations with "indirect financial aid." ${ }^{44} M c G l o t-$ ten held that "there is no question that allowing the deduction of charitable contributions in fact confers a benefit on the organization receiving the contribution," 45 and reiterated the Green characterization of tax deductions as "matching grants";46 and a unanimous three-judge decision in Wolman v. Kosydar ${ }^{47}$ invalidated a scheme of tax credits to parents of children in Ohio parochial schools as violative of the establishment clause, explicitly adopting the functional equivalence theory: "We think that the law is clear that tax exemptions, deductions and credits, like reimbursement grants, are all benefits conferred by the state ...." 48

The Supreme Court also appears to have adopted the functional equivalence theory. In Griffin v. School Board, ${ }^{49}$ the Court

Support of Charities and Other Exempt Organizations: The Need for a National Policy, 20 U. So. CAL. 1968 TAX INST. 27, 32.

${ }^{37}$ Discussion of the case law in this area from a constitutional viewpoint will be postponed to Section IV, infra.

${ }^{38}$ The functional equivalence theory, however, was not explicitly considered in either McCoy v. Shultz, Civ. No. 1580-72 (D.D.C., Feb. 13, 1973), or Junior Chamber of Commerce v. United States Jaycees, No. 73-C-66 (N.D. Okla., Jun. 26, 1973).

State courts have been less uniform in their treatment of the functional equivalence theory. See, e.g., Snyder v. Town of Newtown, 147 Conn. 374, 386, 161 A.2d 770, 776-77 (1960); Murray v. Comptroller of the Treasury, 241 Md. 383, 399, 216 A.2d 897, 906 (1966) (holding tax benefits equivalent to direct grants). But see Traverse City School Dist. v. Attorney General, 384 Mich. 391, 429, 185 N.W.2d 9, 26 (1971).

${ }^{34} 309$ F. Supp. 1127 (D.D.C.), appeal dismissed sub nom. Cannon v. Green, 398 U.S.

956 (1970), sub nom. Coit v. Green, 400 U.S. 986 (1971).

40 Id. at 1136.

${ }^{41} 330$ F. Supp. 1150 (D.D.C.), aff'd mem. sub nom. Coit v. Green, 404 U.S. 997 (1971).

42 Id. at 1164 .

43333 F. Supp. 662 (E.D. Wis. 1971).

${ }^{44}$ Id. at 660 .

4538 F. Supp. at 456 n.37.

${ }^{46} I d$.

${ }^{47}$ Civ. No. 72-222 (S.D. Ohio, Dec. 29, 1972).

${ }^{48} \mathrm{Id}$. at $14-15$.

49377 U.S. 218 (1964). 
upheld a district court's injunction restraining county officials from enforcing two ordinances which gave government aid to private, racially segregated schools. One ordinance provided private school students with tuition grants, and the other allowed parents property tax credits for contributions made to nonsectarian private schools. The district court held that both forms of government assistance to private segregated schools violated the equal protection clause..$^{50}$ Although the Fourth Circuit reversed the lower court's decision on the ground that it should have abstained from deciding the case on the merits, ${ }^{51}$ the court of appeals took note of the impact of the more than $\$ 56,000$ paid out by the county under the tax credit ordinance:

The allowance of such tax credits appears to be an indirect method of channeling public funds to the Foundation [operating the private segregated schools]. ... The allowance of such tax credits makes uncertain the completeness of the County's withdrawal from the school business. It might lead to a contention that exclusion of Negroes by schools of the Foundation is county action. ${ }^{52}$

The Supreme Court's opinion, written by Justice Black, reversed the judgment of the court of appeals and approved the district court's holding:

The injunction against paying tuition grants and giving tax credits while public schools remain closed is appropriate and necessary since those grants and tax credits have been essential parts of the county's program, successful thus far, to deprive petitioners of the same advantages of a public school education enjoyed by children in every other part of V'irginia. ${ }^{53}$

The Court upheld the injunction against both tax credits and direct grants, treating them as equivalent forms of government assistance to racially discriminatory private schools.

Subsequently, Walz v. Tax Commission ${ }^{54}$ gave rise to uncertainty as to the Court's willingness to adopt fully the functional equivalence reasoning. Although the Court characterized the New York property tax exemption for religious and other charitable organizations as an "indirect economic benefit," 55 eight Justices specifically disagreed with Justice Douglas' charac-

so Allen v. County School Board, 198 F. Supp. 497 (E.D. Va. 1961).

51 Griffin v. Board of Supervisors, 322 F.2d 332 (4th Cir. 1963).

52 Id. at 339.

s3 377 U.S. at 233.

54397 U.S. 664 (1970).

${ }^{55}$ Id. at 674 (emphasis added). 
terization of a tax exemption as a subsidy. ${ }^{56}$ This uncertainty appears to have been resolved in Committee for Public Education and Religious Liberty $v$. Nyquist, ${ }^{57}$ in which the Court invalidated a New York statute that provided both tax benefits and direct grants to parents of students in private schools. The Court found a "practical similarity" 58 when it compared the two forms of government assistance to private schools, concluding that "[i]]n practical terms there would appear to be little difference, for purposes of determining whether such aid has the effect of advancing religion, between the tax benefit allowed here and the tuition grant allowed [in another portion of the statute]."59 Five other Justices joined Justice Douglas in Nyquist in equating a tax exemption with a subsidy. Thus, as a matter of economics, the Court appears to have acquiesced in the functional equivalence theory.

Although Bittker and Kaufman do not specifically deny the functional equivalence of tax benefits and direct subsidies, they imply that the theory is unsound. ${ }^{60}$ The basis for their reasoning is found in the Walz opinion. ${ }^{61}$ But, as stated above, such a reading of Walz now has been severely undermined by the Court's opinion in Nyquist. It now seems beyond contention that tax benefits will continue to be recognized as functional economic equivalents of direct government expenditures.

\section{Government Involvement With Private Conduct}

Although all tax benefits confer economic subsidies on their recipients, the process of allocating these subsidies may differ so significantly from the process of allocating direct expenditures that these economically equivalent measures differ in constitutional significance. Additionally, important differences may exist among the various types of tax benefits themselves, instilling them with disparate constitutional consequences. Thus, the constitutional significance of tax benefits can only be determined after a complete analysis of the facts and circumstances of the resulting government involvement in private affairs.

The departure points for the construction of a theoretical framework for the application of constitutional restrictions to tax incentives and other forms of government involvement with private conduct are the broad standards set forth by the Su-

\footnotetext{
${ }^{56} I d$. at 709 (Douglas, J., dissenting).

5793 S. Ct. 2955 (1973).

${ }^{58}$ Id. at 2976 .

${ }^{59}$ Id. at 2974.

${ }^{60}$ See Taxes and Civil Rights, supra note 7, at 63 n.37.

${ }^{61} \mathrm{Id}$.
} 
preme Court in Burton v. Wilmington Parking Authority ${ }^{62}$ for equal protection and due process claims, and in Lemon v. Kurtzman ${ }^{63}$ for claims under the establishment of religion clause of the first amendment. In Burton the Court observed that "private conduct abridging individual rights does no violence to the Equal Protection Clause unless to some significant extent the State in any of its manifestations has been found to have become involved in it." 64 The Court suggested that government involvement should be deemed significant if

the State has so far insinuated itself into a position of interdependence with [the private discriminator] that it must be recognized as a joint participant in the challenged activity, which, on that account, cannot be considered to have been so "purely private" as to fall without the scope of the Fourteenth Amendment. ${ }^{65}$

But the Court deliberately declined to spell out a more specific standard, explaining: "Only by sifting facts and weighing circumstances can the nonobvious involvement of the State in private conduct be attributed its true significance." 66

In Lemon v. Kurtzman the Court enunciated a three-pronged test for determing the constitutionality of government involvement with religious organizations: "First, the statute must have a secular legislative purpose; second, its principal or primary effect must be one that neither advances nor inhibits religion ... [;] finally, the statute must not foster an excessive government entanglement with religion." 67 The Lemon test is essentially a sifting and weighing test like the Burton test.

Although the vagueness of the two standards has allowed the courts a degree of flexibility that is essential for the evaluation of the multitude of relationships that arise between government and private conduct, it has also fostered considerable uncertainty. It is the purpose of this section to move beyond the broad guidelines of Burton and Lemon, toward a comprehensive set of standards for determining in a given situation whether the government is sufficiently involved with an otherwise private entity to activate constitutional restrictions. No simple formula will be produced, but an attempt will be made to lay out the factors involved in such a determination and weigh their significance. The inquiry entails a consideration of four elements: the nature and degree of government involvement with

62365 U.S. 715 (1961).

63403 U.S. 602 (1971).

64365 U.S. at 722 (emphasis added).

${ }^{65} I d$. at 725 (emphasis added).

${ }^{66} \mathrm{Id}$. at 722 .

67403 U.S. at $612-13$. 
the otherwise private entity; the nexus between the government involvement and the challenged private activity; the nature of the conduct engaged in by the private entity-that is, the "privateness" or "publicness" of the conduct; and the nature of the consitutional claim-that is, whether the conduct is alleged to violate rights of equal protection, of due process or of religion.

\section{A. The Nature and Degree of Government Involvement}

An evaluation of the nature and degree of government involvement in challenged private conduct hinges upon several closely related questions: whether there is government approval or control of the private entity and its activities; the relative quantitative significance of government assistance, as compared to the other resources of the entity; and whether the government involvement provides some part of what this Comment will call the "basic package" of government benefits.

\section{Government Approval}

The guarantees of freedom of religion, due process and equal protection impose restrictions on the objectives and methods to which the government may lend its "power, property and prestige." 68 Affirmative government approval of private conduct is clearly one sort of government action which these guarantees may proscribe under appropriate circumstances.

The difficult question is what constitutes a stamp of government approval. Certain governmental activities have already been held insufficient to constitute impermissible approval of private discrimination-notably, granting liquor licenses ${ }^{69}$ and legislative charters. ${ }^{70}$ Other government activities, including the granting of tax incentives, entail varying degrees of government approval, which may or may not justify a finding that the government has placed its imprimatur on the conduct in question. Although a full discussion of the degree of government approval that accompanies particular tax incentives will be deferred to Section IV, it is useful at this point to offer some general observations.

It has been argued that tax incentives involve significantly less government approval of private conduct than direct expenditures. ${ }^{71}$ Direct expenditure programs, it is said, are usu-

${ }^{68}$ Burton v. Wilmington Parking Auth., 365 U.S. at 725. In Walz v. Tax Comm'n, 397 U.S. 664,675 (1970), it was government "sponsorship" of religious activities that the Court looked for.

${ }_{69}$ Moose Lodge No. 107 v. Irvis, 407 U.S. 163 (1972).

${ }^{70}$ Stearns v. Veterans of Foreign Wars, 353 F. Supp. 473 (D.D.C. 1972).

71 The argument may have been endorsed by the Supreme Court in Walz v. Tax Comm'n, 397 ن.J. $6 \tilde{64}, 675$ (1970). See text accompanying notes $168-70$ infra. But see 
ally accompanied by detailed and stringent restrictions upon the activities of private recipients, whereas tax incentives are typically granted without regard to the policies of their beneficiaries. Although federal grants, in particular, often require recipients to certify that they do not discriminate, tax incentives frequently impose only minimal restrictions upon the activities of their recipients-such as the vague requirement that they engage in "charitable activities."

While this may be true in general, it is important to note that the difference in the degree of government approval which might appear between tax incentives and direct expenditures is not a function of any intrinsic difference in the processes by which or the conditions upon which these subsidies are granted. ${ }^{72}$ Tax incentive schemes run the gamut from the broad charitable deduction to the carefully tailored tax credits and deductions struck down in Griffin v. School Board ${ }^{73}$ and Committee for Public Education and Religious Liberty v. Nyquist. ${ }^{74}$ The Griffin and Nyquist schemes were designed with a degree of specificity and restrictiveness comparable to most direct expenditure programs. Indeed, they were more restrictive than some direct expenditure programs-for example, G.I. Bill payments, veterans' housing subsidies, social security benefits, civil service benefits and the payment of government salaries. The stamp of government approval does not attach automatically to the activities of the recipients of direct government expenditures, ${ }^{75}$ nor is it necessarily withheld from activities which are aided by government tax incentives.

Several courts have explicitly acknowledged the possibility that government approval may accompany tax incentives. For example, the McGlotten court described the effect of Internal Revenue Service determinations of eligibility for the section 170 deduction and the section 501 exemption as follows: "Thus the government has marked certain organizations as 'Government Approved' with the result that such organizations may solicit funds from the general public on the basis of that approval."76 Similarly, the district court in Falkenstein v. Department of Revenue

Committee for Public Education and Religious Liberty v. Nyquist, 93 S. Ct. 2955, 2976 (1973).

${ }_{72}$ See Tax Incentives, supra note 1 , at 716-18.

73377 U.S. 218 (1964). See text accompanying notes 52-56 supra.

7493 S. Ct. 2955 (1973).

${ }^{75}$ In his concurring and dissenting opinion in Nyquist, Chief Justice Burger said:

There are at present many forms of government assistance to individuals that can be used to serve religious ends, such as social security benefits or "G.I. Bill" payments, which are not subject to nonreligious use restrictions. Yet, I certainly doubt that today's majority would hold those statutes unconstitutional under the Establishment Clause.

93 S. Ct. at 2991-92.

${ }_{76} 338 \mathrm{~F}$. Supp. at 456. 
concluded that Oregon, by granting a charitable exemption, "places its stamp of approval on the Elks Lodge as an organization that furthers the legislative policy of the State."77

The essence of the concept of government approval is the impression that the government action creates among the public. Eligibility for favorable tax treatment certainly implies government approval in some sense, but does not necessarily imply approval of all conduct engaged in by the favored entity. Thus, for example, the public may interpret the granting of tax exempt status to a racially discriminatory school not as an indication of government approval of the discrimination, but simply as an indication that the school passed some red-tape test which took no account of the school's racial policies. The former brand of approval would clearly be of greater significance to a determination whether the discrimination can be termed state action. In each case, therefore, we should not inquire simply whether or not a tax incentive or other government benefit indicates government approval of an entity in some sense, but to what aspects of the favored entity's activities that approval extends in the public's view.

\section{Government Regulation}

The concept of government control over or regulation of an entity's activities is closely related to the concept of government approval. Government control over. an activity, like approval, may affect the extent to which that activity partakes of the government's "power, property and prestige." 78 Not surprisingly, control and approval often go hand in hand.

The conclusion reached with respect to the relative degrees of government approval inherent in tax incentives and direct expenditures is equally applicable to the relative degrees of control inherent in them: while legislatures have often chosen to fashion tax incentives with few strings attached, there is nothing inherent in a tax incentive which prevents the government from exercising the same degree of control over tax-favored activities that it exercises over activities favored by direct government expenditures. Each tax incentive scheme, like each expenditure program, must be subjected to individual scrutiny.

A line of cases dealing with private hospitals receiving federal grants under the Hill-Burton Act serves to illustrate the operation of government control and regulation in transforming private conduct into constitutionally prohibited conduct, in both

${ }^{71} 350$ F. Supp. 887, 889 (D. Ore. 1972). See also Green v. Kenneđy, 309 F. Supp. 1127, 1135 (D.D.C.), appeal dismissed sub nom. Cannon v. Green, 398 U.S. 956 (1970), sub nom. Coit v. Green, 400 U.S. 986 (1971).

${ }^{78}$ Burton v. Wilmington Parking Auth., 365 U.S. at 725. 
the due process and the equal protection settings. Simkins $v$. Moses H. Cone Memorial Hospital ${ }^{79}$ held that private hospitals participating in the Hill-Burton program were bound by the equal protection clause under Burton v. Wilmington Parking Authority. ${ }^{80}$ The significant aspects of government identified in Simkins were the "massive use of public funds," 81 the public function performed by the hospitals, and the "elaborate and intricate pattern of governmental regulations, both state and federal." 82 The regulations enforced by an agency of the state provided in detail for all aspects of the management of the hospitals-administration, clinical services, auxiliary services, nursing services and food services. In the words of the Fourth Circuit in another Hill-Burton case, in which the court found state action in the activities of a hospital which received no Hill-Burton funds but which was nevertheless subject to the Hill-Burton regulations, the regulations "effectively controll[ed] the full range of day-to-day hospital administration and operation." 83 The degree of control exercised by the state and federal governments under the Hill-Burton Act, combined with the other factors mentioned in Simkins, resulted in findings of state action in the operation of hospitals in a number of due process and equal protection cases involving varying degrees of government funding. ${ }^{84}$

\section{Quantitative Significance of Government Assistance}

An evaluation of the degree to which private activity is supported by the government's "power, property and prestige,"

\footnotetext{
79323 F.2d 959 (4th Cir. 1963), cert. denied, 376 U.S. 938 (1964).

80365 U.S. 715 (1961).

81323 F.2d at 967 .

${ }^{82} I d$. at $964-65,967-68$.
}

${ }^{83}$ Eaton v. Grubbs, 329 F.2d 710, 713 (4th Cir. 1964). The hospital did receive city and county construction funds and a tax exemption.

${ }_{84}$ Courts found state action in the following cases involving due process claims: Chiaffitelli v. Dettmer Hosp., Inc., 437 F.2d 429 (6th Cir. 1971) (Hill-Burton funds accounted for $8 \%$ of the hospital's operating budget, and county funds accounted for $6 \%$ ); Sosa v. Board of Managers of Val Verde Mem. Hosp., 437 F.2d 173 (5th Cir. 1971) (funding not specified); Sams v. Ohio Valley Gen. Hosp. Ass'n, 413 F.2d 826 (4th Cir. 1969) (Hill-Burton funds covered about one-third of the cost of one construction project and one-half the cost of another); Meredith v. Allen County War Mem. Hosp. Comm'n, 397 F.2d 33 (6th Cir. 1968) (funding not specified); Citta v. Delaware Valley Hosp., 313 F. Supp. 301 (E.D. Pa. 1970) (Hill-Burton funds covered about one-third of construction costs).

Courts found state action in the following cases involving racial discrimination: Cypress v. Newport News Gen. and Nonsectarian Hosp. Ass'n, 375 F.2d 648 (4th Cir. $1967)(\$ 2,250,000$ in Hill-Burton funds); Smith v. Hampton Training School for Nurses, 360 F.2d 577 (4th Cir. 1966) (\$1.7 million in Hill-Burton funds).

A district court, in a free exercise case, found state action in the operation of a hospital which was not alleged to have received Hill-Burton funds, but which was subject to a "system of pervasive regulation" similar to that in Simkins. Holmes v. Silver Cross Hosp., 340 F. Supp. 125, 133 (N.D. Ill. 1972). 
or is imbued with government "sponsorship,"85 necessarily entails an inquiry into the significance of the government assistance in relation to the total amount of resources consumed by the activity. ${ }^{86}$ This inquiry has been undertaken frequently by the courts, and has resulted in determinations that no state action existed in the following disparate circimstances: when government funds comprised $4 \frac{1}{2} \%$ of a private hospital's total operating budget; ${ }^{87}$ when the net advantage of a state property tax exemption to a private university amounted to $.82 \%$ of the university's costs; ${ }^{88}$ when a private college received $3 \%$ public funding; ${ }^{89}$ and when a school was operated with $23 \%$ public funds..$^{90}$ Under this quantum theory, state action was found with respect to a library that received $99 \%$ of its operating budget from a municipal government. ${ }^{91}$

A few courts have criticized the tendency to use a quantum analysis as the exclusive index of state action. In the Hill-Burton cases, the courts found constitutional violations, despite the fact that government expenditures were an extremely small percentage of the operating budget of private hospitals. ${ }^{92}$ And in Grossner v. Trustees of Columbia University, ${ }^{93}$ the court wrote that

receipt of money from the State is not, without a good deal more, enough to make the recipient an agency or instrumentality of the Government. Otherwise, all kinds of contractors and enterprises, increasingly dependent upon government business for much larger proportions of income than those here in question, would find themselves charged with "state action" in the performance of all kinds of functions we still consider and treat as essentially "private" for all presently relevant purposes.

But the percentage of government resources utilized by private entitities is nonetheless a significant aspect of government involvement. As Judge Wisdom suggested in Poindexter $v$. Louisiana Financial Assistance Commission: "Where there is no evidence of purposeful participation in private discrimination, the percentage of state aid is relevant." 94

\footnotetext{
${ }^{85}$ Walz v. Tax Comm'n, 397 U.S, 664, 668 (1970).

${ }^{86}$ The quantum theory is thoroughly discussed in Note, Federal Tax Benefits to Segregated Private Schools, 68 Colum. L. Rev. 922, 929-30 (1968).

87 Eaton v. Board of James Walker Mem. Hosp., 261 F.2d 521 (4th Cir. 1958). For subsequent litigation concerning this hospital, see note 83 supra \& accompanying text; text accompanying notes $149-50$ infra.

${ }^{88}$ Guillory v. Administrators of Tulane Univ., 212 F. Supp. 674 (E.D. La. 1962).

${ }^{89}$ Powe v. Miles, 407 F.2d 73 (2d Cir. 1968).

${ }^{90}$ Norris v. Mayor of Baltimore, 78 F. Supp. 451 (D. Md. 1948).

91 Kerr v. Enoch Pratt Free Library, 149 F.2d 212 (4th Cir. 1945).

${ }^{92}$ See note 84 sutpra.

93287 F. Supp. 535, 547-48 (S.D.N.Y. 1968).

94275 F. Supp. 833, 855 (E.D. La. 1967), aff'd per curiam, 389 U.S. 571 (1968).
} 
4. The "Basic Package" of Government Benefits and Services

The last significant inquiry into the nature and degree of government involvement is whether that involvement takes the form of provision of part of the "basic package" of government benefits. The recent Supreme Court decisions in Norwood $v$. Harrison $^{95}$ and Nyquist seem to suggest that there is such a basic package of government-furnished benefits and services that does not carry with it constitutional restrictions. The composition of that basic package of benefits and services has by no means been defined, but the Norwood and Nyquist decisions offer some noteworthy observations. In Norwood, the Court stated:

We do not suggest that a State violates its constitutional duty merely because it has provided any form of state service that benefits private schools said to be racially discriminatory. Textbooks are a basic educational tool and, like tuition grants, they are provided only in connection with schools; they are to be distinguished from generalized services government might provide to schools in common with others. Moreover, the textbooks provided to private school students by the State in this case are a form of assistance readily available from sources entirely independent of the State .... The State has neither an absolute nor operating monopoly on the procurement of school textbooks; anyone can purchase them on the open market. ${ }^{96}$

Nyquist offered a similar, but not identical, statement in the establishment-of-religion context:

Such services [police and fire protection, sewage disposal, highways and sidewalks], provided in common to all citizens, are "so separate and so indusputably marked off from the religious function," . . . that they may fairly be viewed as reflections of a neutral posture toward religious institutions . . . The Court [in Board of Education $v$. Allen] repeatedly emphasized that ... there was no indication that textbooks would be provided for anything other than purely secular courses. ${ }^{97}$

Three criteria for the determination of the content of the basic package emerge from these two statements. First, in Nyquist the Court found significance in the fact that the benefits were separate from the religious function of the school. It is no simple matter to determine whether a benefit is clearly separate from

9593 S. Ct. 2804 (1973).

${ }^{96} I d$. at $2810-11$.

9793 S. Ct. at 2970. 
the religious function of a religious school. Any benefit will free funds for expenditure on matters directly related to its religious function. The Nyquist criterion of separateness of function is, therefore, of limited use in defining, in the establishment of religion context, the contents of the basic package of government benefits. After Norwood any related criterion is simply irrelevant in the equal protection context. ${ }^{98}$

Second, the Norwood Court focused on whether the state had "an absolute or operating" monoply on the distribution of the particular benefit. The concept of government monopoly on the distribution of a particular benefit is a useful one. ${ }^{99}$ But the language quoted above should not be read to mean that only benefits and services available exclusively from the government should be considered elements of the basic package. Postal service, for example, is available from private sources, but would clearly be part of the basic package of government benefits and services. The Norwood language should be read for the proposition that a benefit or service that is "readily available"100 from the government and that is generally obtained from the government rather than from private sources is a likely candidate for inclusion in the basic package that will not activate constitutional restrictions. ${ }^{101}$

Third, both Norwood and Nyquist found that distribution to a wide range of people was a distinguishing feature of the elements of the basic package. Norwood spoke of services that the government provides to schools in common with others; but the Nyquist language referring to services provided in common to all citizens provides a more suitable definition of the basic package. Certainly the fact that the state may provide textbooks to libraries and day care centers, in addition to schools, would not throw the provision of textbooks into the basic package. The government can single out several entities as well as it can single

${ }^{98}$ Compare Board of Educ. v. Allen, 392 U.S. 236 (1968) (provision of textbooks to private sectarian schools does not violate the establishment clause), with Norwood v. Harrison, 93 S. Ct. 2804 (1973) (provision of textbooks to a private discriminatory school violates the equal protection guarantee).

${ }^{99}$ The Norwood notion of government monopoly is consonant with the cases which have held that private conduct is not transformed into impermissible state action by the granting of legislative charters and liquor licenses. Corporation charters, marriage and driver's licenses, and building permits would also fall into this category.

${ }^{100}$ Text accompanying notes $95-96$ supra.

${ }^{101}$ It might be argued that since tax incentives are available only from the government, all tax incentives fall within the basic package. But this argument fails for 2 reasons. First, exclusive distribution by the government may not by itself place a benefit within the basic package. Second, and more importantly, the relevant inquiry in the case of tax incentives is whether the economic benefit provided by the government through the tax incentive is of the sort provided exclusively by the government, not whether the tax incentive itself can only be provided by the government. In fact, a tax incentive would rarely, if ever, meet the Norwood monopoly standard, for the benefit provided through tax incentives is a general monetary one which could presumably be supplied through numerous other channels. 
out one entity, and the basic package should consist of benefits that are so widely available that no entity or entities can be considered to be singled out.

It might be suggested that the government may pay for whatever it requires a private entity to do, without activating constitutional restrictions-that is, that government assistance which helps a private entity to conform to state-imposed regulations, such as requirement of minimum lighting or sanitary facilities in a school, falls within the basic package of government benefits and services. But the Court explicitly rejected this contention in Levitt v. Committee for Public Education and Religious Liberty, ${ }^{102}$ an establishment of religion case. Since what constitutes state action for purposes of the establishment clause does not necessarily constitute state action for purposes of the equal protection clause, ${ }^{103}$ the Levitt principle does not necessarily apply in cases of discrimination. But the question whether the activity made possible by the government assistance is required by the government does not seem particularly pertinent to the inquiry which underlies the determination of the contents of the basic package-namely, whether the government involvement is of a kind that cannot be seen as offering support for a particular entity and its activities.

While no comprehensive definition of the basic package has emerged from this brief discussion, the second and third criteria drawn from the Norwood and Nyquist opinions can be combined to form a broad definition suitable for purposes of this Comment. The basic package of government benefits and services, the provision of which does not activate constitutional restrictions, consists of those benefits and services which are generally provided by the government rather than by private entities, and which, when provided by the government, are available to the public at large.

\section{B. The Nexus Between the Government Involvement and the Challenged Private Action}

The government is involved, in one way or another, with a vast number of private entities, and a wide range of different activities. Once it is concluded that government involvement with an otherwise private entity is capable of transforming some of the activities of that entity into state action, the obvious question becomes which of these activities can be so transformed.

Judge Friendly offered some observations on the requisite connection between the government involvement and the chal- 
lenged activity in Powe $v$. Miles. ${ }^{104}$ In that case, the Second Circuit held that Alfred University's establishment and enforcement of demonstration guidelines constituted state action with respect to students in the entirely state-supported New York State College of Ceramics located on the Alfred University campus, but did not constitute state action with respect to students in Alfred's liberal arts college, which received a small amount of state aid. In rejecting the contention that the state's regulation of educational standards in the university transformed the university's disciplinary policies into state action, Judge Friendly noted:

[T] he state must be involved not simply with some activity of the institution alleged to have inflicted injury upon a plaintiff but with the activity that caused the injury. Putting the point another way, the state action, not the private action, must be the subject of complaint. ${ }^{105}$

In other words, Powe indicates that the existence of state regulation or the imposition of state standards will not transform into state action those activities of a private institution that are not subject to the regulations or standards.

Financial assistance is, of course, different from regulation; and in this regard, Judge Friendly held that the amount of state assistance provided to the liberal arts college was "a long way from being so dominant as to afford basis for a contention that the state is merely utilizing private trustees to administer a state activity." 106 Although the only case cited by Judge Friendly at this point in his opinion was a case in which the entity (a library) was completely owned and supported from its inception by the state, ${ }^{107}$ his opinion at least leaves open the possibility that partial financial assistance could give rise to state action.

The Tenth Circuit addressed the question of the significance of general financial assistance to a private university in Browns $v$. Mitchell. ${ }^{108}$ In holding that a special tax exemption did not convert a university's disciplinary policies into state action, the court explained that

there is nothing in the record to indicate that [the tax exemption] is or can be utilized in any way to dictate or influence the administration of University affairs. And even more critically, there is no suggestion that the claimed involvement is in any way associated with the

${ }^{104} 407$ F.2d 73 (2d Cir. 1968).

${ }^{105} I d$. at 81 .

${ }^{106} \mathrm{Id}$.

${ }^{107}$ Kerr v. Enoch Pratt Free Library, 149 F.2d 212 (4th Cir. 1945).

108409 F.2d 593 (10th Cir. 1969). 
challenged activity .... The benefits conferred, however characterized, have no bearing on the challenged actions beyond the perpetuation of the institution itself. ${ }^{109}$

Although the Browns court noted that the university received no state funds, ${ }^{110}$ the case, particularly the language quoted above, can be read for the proposition that government financial assistance that contributes generally to the perpetuation of an entity will not give rise to state action-that only direct state involvement with the specific challenged activity justifies a finding of state action. Under this restrictive theory, a private foundation that receives federal funds to operate day care facilities could constitutionally exclude all black applicants, unless it could be shown that the government was directly involved in the decision to discriminate. This theory is unacceptable. The suggestion that general financial assistance to an entity cannot transform any specific activity of that entity into state action suffers from a serious flaw: it incorrectly assumes that government involvement that bears directly upon a specific activity of an entity can be meaningfully distinguished from government involvement that serves more generally to perpetuate that entity as a whole. It is an inescapable fact that general government assistance which perpetuates an entity operates indirectly to perpetuate the specific activities of that entity. In the example of the foundation that discriminates in making available its day care services, government financial assiatance serves to continue that discrimination.

The restrictive nexus theory that can be drawn from Browns is at odds with the result reached by the Supreme Court in Burton v. Wilmington Parking Authority. In Burton, a discriminatory private restaurant leased space from a parking authority in a public garage building. The government involvement was nonspecific, merely helping to perpetuate the restaurant as an economically viable enterprise. There was no government involvement with the decision of the restaurant owner not to serve black persons. Yet the Court found state action. ${ }^{111}$

In McGlotten v. Connally, ${ }^{112}$ the district court applied a nexus theory that was slightly less restrictive than that suggested by Browns. McGlotten held that government involvement serving merely to perpetuate a private entity, and not directed to any specific activity of that entity, could be sufficient to activate the equal protection clause if the private entity is one of those "particular organizations with particular puposes" that are

${ }^{109} I d$. at 596 .

${ }^{110} I d$. at 595 .

111365 U.S. 715 (196I).

112338 F. Supp. 448 (D.D.C. 1972). 
selected and, in effect, approved (along with their discriminatory practices) by the government. ${ }^{113}$ The McGlotten court suggested that deductions for mortgage interest ${ }^{114}$ and accelerated depreciation for rehabilitated low income rental property, ${ }^{115}$ while acting as incentives, would not trigger constitutional restrictions because, unlike charitable deductions for contributions to fraternal orders, they do not expressly choose any organizations as vehicles. Bittker and Kaufman severely criticize this "chosen instrumentality" theory in Taxes and Civil Rights, and there is no need to elaborate upon their thorough and valid objections, ${ }^{116}$ beyond repeating part of their response to the McGlotten court's distinction between the deductions allowed by section 170 for charitable contributions and by section $167(\mathrm{k})$ for rehabilitating low-income rental housing:

[Section] 167(k) is more clearly in purpose, and probably in effect, an incentive to taxpayer behavior than the tax exemption for fraternal orders. Since the issue under Wilmington Parking Authority is the extent of governmental encouragement of the activity that discriminates, the fact that $\S 167(\mathrm{k})$ was clearly intended to increase the supply of a particular type of housing seems to suggest that it is at least as vulnerable as $\S$ $170(c)(4)$, encouraging charitable contributions to fraternal orders, and more vulnerable than $\S 501(\mathrm{c})(8)$, exempting the fraternal order's own income, for these provisions demonstrate no clear purpose to encourage [private activity]. ${ }^{117}$

A better nexus theory, which would avoid some of the problems posed by Browns and McGlotten, would focus less on the specificity of the government involvement and more on the particular activity undertaken by the private entity. Under this modified nexus theory, the only private activities that could be transformed into state action would be those undertaken by a private entity in the normal course of accomplishing the objectives intended by the legislature to underlie the government involvement. In the case of a tax incentive, this governmentobjective nexus theory would subject to constitutional scrutiny only those private activities pursued by beneficiaries of the tax incentive for the purpose of accomplishing the objectives which the tax incentive was intended to advance.

This theory does not avoid every defect of the alternatives. A question remains: what relation must there be between the

${ }^{113} I d$. at 459.

${ }^{114}$ INT. Rev. CoDE of 1954, \& 163.

115 Id. § $167(\mathrm{k})$.

${ }^{116}$ Taxes and Civil Rights, supra note 7, at 68-74.

${ }^{117}$ Id. 73. 
objective of the tax incentive and the challenged private conduct in order to find a violation of the equal protection clause? For example, if a private contractor who receives deductions under section $167(\mathrm{k})$ for housing rehabilitation were to refuse to sell his personal residence to a prospective buyer on racial grounds, would his refusal constitute state action? What if the contractor were to refuse to hire laborers or purchase building materials from wholesalers on racial grounds? It could be argued that only the contractor's refusal to rent apartments after the completion of the project could activate constitutional sanctions. The intended beneficiaries of the tax deduction are the prospective unit dwellers (low income citizens in need of housing), although the contractor and his subcontractors and employees certainly derive economic benefit from the deduction. Why, the argument goes, should the manner in which the construction of that housing was undertaken be of any constitutional significance? On the other hand, one could argue that Congress intended to encourage construction of the units by enacting the exemption, so that construction must comply with constitutional norms. Which activities are drawn into the category of state action will depend on their perceived relationship to carrying out the legislature's objective.

The government-objective nexus theory supports the decision of the Supreme Court in Norwood. In that case, the Court held that the provision of free textbooks to students in private racially discriminatory schools was state action for purposes of the equal protection clause. The nature of the government benefit was nonspecific: the provision of textbooks supported the discriminatory schools by allowing them to allocate their funds for other necessary expenditures, but it did not involve the government directly with the decision made by the schools to exclude blacks. The Norwood Court explained:

Free textbooks, like tuition grants directed to private school students, are a form of financial assistance inuring to the benefit of the private schools themselves. An inescapable educational cost for students in both public and private schools is the expense of providing all necessary learning materials. When, as here, that necessary expense is borne by the State, the economic consequence is to give aid to the enterprise; if the school engages in discriminatory practices the State by tangible aid in the form of textbooks thereby gives support to such discrimination. ${ }^{118}$

In reaching its conclusion the Norwood Court rejected the argument that the provision of textbooks could not constitute 
state action in support of discrimination because the benefit was to the parents and the children, not to the schools. ${ }^{119}$ The Nyquist Court rejected a similar argument in the establishment-ofreligion context. ${ }^{120}$ Both decisions are noteworthy for their willingness to look beyond the form of the government involvement to the nature of the indirect benefit which flowed to the private entity.

The Norwood case is unlike the Griffin and Nyquist cases, in which the government involvement was tailored to achieve specific objectives by attempting to circumvent prior holdings of the Court. The Mississippi statute which authorized the textbook program challenged in Norwood was enacted in 1940, long before the Supreme Court's decision in Brown v. Board of Education, ${ }^{121}$ and "consequently, long before there was any occasion to have a policy or reason to foster the development of racially segregated private academies." ${ }^{22}$ The Norwood holding provides strong support for the contention that any government benefit, including a tax incentive, which is not included in the basic package attaches the label of state action to conduct taken in pursuit of the objectives which the benefit was designed to serve, regardless of the lack of legislative intent to foster discrimination or circumvent constitutional requirements.

Even under the government-objective nexus theory outlined above, it remains necessary to determine how close a connection there must be between the government objective and the challenged conduct. What has been offered is merely an approach to the constitutional evaluation of the nexus between government involvement and the challenged conduct. This approach is better suited to the evaluation of tax incentives, which contemplate the inducement by the government of certain kinds of conduct, than either the restrictive Browns approach or the McGlotten chosen instrumentality approach. And since the government-objective nexus theory is in harmony with the Supreme Court's current position as expressed in Norwood, the McGlotten chosen instrumentality theory, devised before Norwood, is no longer an appropriate constitutional standard for evaluating tax incentives.

\section{The Nature of the Conduct Engaged in by the Private Entity}

\section{Privateness}

Any theoretical framework constructed to guide the application of constitutional restrictions to government involvement

119 Id. at 2810.

12093 S. Ct. at 2969-72.

121347 U.S. 483 (1954).

$12293 \mathrm{~S}$. C. at 2808. 
with private conduct must take into account the constitutional vectors which countervail the equal protection, due process and establishment clauses-the freedoms of speech, religion and assembly. These constitutional guarantees are at the heart of the concept of "privateness," and may in some cases operate to forbid the denial of government benefits and services to private entities.

The Supreme Court has ruled that the first amendment freedom of speech prohibits the government from conditioning benefits on the expression of a particular political belief. In Speiser $v$. Randall, ${ }^{123}$ the Court invalidated a California statute that required all who claimed real property tax exemptions to sign a statement disavowing involvement with any activity advocating the violent overthrow of the government of either the United States or the State of California. The Court distinguished the case from others sustaining the validity of loyalty oaths required of public employees, candidates for public office and officers of labor unions, on the ground that in those cases "there was no attempt directly to control speech but rather to protect, from an evil shown to be grave, some interest clearly within the sphere of governmental concern."124 The Court held that

a discriminatory denial of a tax exemption for engaging in speech is a limitation on free speech. . . . To deny an exemption to claimants who engage in certain forms of speech is in effect to penalize them for such speech. Its deterrent effect is the same as if the State were to fine them for this speech. ${ }^{125}$

The Court has also held that the free exercise clause of the first amendment imposes restrictions on the freedom of the government to withhold benefits. In Sherbert $v . V e r n e r,{ }^{126}$ a Seventh Day Adventist was disqualified from receiving unemployment compensation benefits under the South Carolina Unemployment Compensation Act, which provided that a claimant was ineligible for benefits if "he has failed without good cause ... to accept available suitable work when offered him by the employment office or the employer." ${ }^{127}$ The Seventh Day Adventist was offered employment which required working Saturday, and refused to accept it because Saturday is the sabbath day of her religion. The Supreme Court held that "to condition the availability of benefits upon this appellant's willingness to violate a cardinal principle of her religious faith

123357 U.S. 513 (1958).

${ }^{124} I d$. at 527.

${ }^{125}$ Id. at 518 .

126374 U.S. 398 (1963).

${ }^{127} \mathrm{Id}$. at 401 . 
effectively penalizes the free exercise of her constitutional liberties.

The zone of protection offered by the first amendment freedoms is not, however, without limits. Although the Court did extend protection to religiously dictated conduct in Sherbert, it drew a distinction between government regulation of religious belief and regulation of religiously dictated conduct, indicating that conduct may be regulated under certain circumstances:

The door of the Free Exercise Clause stands tightly closed against any governmental regulation of religious beliefs as such . . . . Government may neither compel affirmation of a repugnant belief, ... nor penalize or discriminate against individuals or groups because they hold religious views abhorrent to the authorities .... On the other hand, the Court has rejected challenges under the Free Exercise Clause to governmental regulation of certain overt acts prompted by religious beliefs or principles, for "even when the action is in accord with one's religious convictions, [it] is not totally free from legislative restrictions." 129

Likewise, the Court in Speiser was careful to point out that "[f]or the purposes of this case we assume without deciding that California may deny tax exemptions to persons who engage in the proscribed speech for which they might be fined or imprisoned." 130

Although speech may constitutionally be regulated under narrow circumstances, ${ }^{131}$ there is in the freedom of speech context a distinction between expression of ideas and action taken pursuant to ideas, ${ }^{132}$ which is similar to the distinction in the free exercise context between religious belief and religiously dictated conduct. This distinction between expression and action can be illustrated by three recent lower federal court decisions. In Joyner $v$. Whiting, ${ }^{133}$ the Fourth Circuit held that the hiring or advertising policy of a state college newspaper would constitute conduct in violation of the equal protection clause if students were denied the opportunity to write for the newspaper, or if advertisers were denied the opportunity to advertise, on racial grounds. However, Joyner held that the advocacy by a state college newspaper of a racist belief as editorial policy was expres-

${ }^{128} I d$. at 406 .

${ }^{129} I d$. at $402-03$.

130357 U.S. at $519-20$

${ }^{131}$ See Dennis v. United States, 341 U.S. 494 (1951).

${ }^{132}$ Indeed, in Yates v. United States, 354 U.S. 298 (1957), the Court explained that the regulation of speech in Dennis was proper because the speakers were urging people to do something, not just to believe in something.

${ }^{133} 477$ F.2d 456 (4th Cir. 1973). 
sion protected by the first amendment freedom of speech. Likewise, in Auerbach v. African American Teachers Association, Inc., ${ }^{134}$ the forcible exclusion of white teachers by black teachers from a meeting held in a public school auditorium with permission of the school's principal was held to be conduct in violation of the equal protection clause, while in National Socialist White People's Party $v$. Ringers ${ }^{135}$ the right of a white racist group to utilize for the expression of racist views a public auditorium available for rental on a first-come-first-serve basis was held to be protected by the first amendment.

The existence of limitations on the zone of protection offered by the first amendment guarantees raises the important question whether racial discrimination practiced pursuant to religious beliefs or simply out of a desire to choose one's own associates is constitutionally protected, or whether the government may deny benefits to racially discriminatory entities. This question was directly addressed in the free exercise context by a federal district court in Bob Jones University v. Connally. ${ }^{136}$ Bob Jones University is a private religious university which openly follows racially discriminatory policies based upon religious beliefs. In Bob Jones, the district court preliminarily enjoined the Internal Revenue Service from removing the university's taxexempt status under an IRS regulation regarding private racially discriminatory schools. Although the court was not explicit on this point, it appears that the injunction was issued on the ground that removing the university's section 501(c)(3) qualification would violate the university's first amendment right of free exercise of religion. ${ }^{137}$ The court distinguished Green $v$. Kennedy, ${ }^{138}$ in which a three-judge court preliminarily enjoined the Secretary of the Treasury from granting tax-exempt status to racially discriminatory schools, on the ground that the racially discriminatory policy of Bob Jones University, unlike the policy of the schools in Green, "is, and always has been, based on religious considerations." 139 The Supreme Court will shed some light on the degree of protection afforded religiously dictated discriminataion when it reviews the Bob Jones decision. ${ }^{140}$

${ }^{134} 356$ F. Supp. 1046 (E.D.N.Y. 1973).

135473 F.2d 1010 (4th Cir. 1973).

136341 F. Supp. 277 (D.S.C. 1971), rev'd on other grounds, 472 F.2d 903 (4th Cir.) cert. granted, 94 S. Ct. 116 (1973).

${ }_{137} 309$ F. Supp. 1127 (D.D.C.), appeal dismissed sub nom. Cannon v. Green, 398 U.S.

956 (1970), sub nom. Coit v. Green, 400 U.S. 986 (1971).

138341 F. Supp. at 285 n.5.

${ }^{139} \mathrm{Id}$. at 285 .

140 Dictum offered by Judge Leventhal in Green v. Connally, $330 \mathrm{~F}$. Supp. 1150

(D.D.C.), aff'd, 404 U.S. 997 (1971), suggests an opposite result from the Bob Jones result:

We are not now called upon to consider the hypothetical inquiry whether tax-exemption or tax-deduction status may be available to a religious school that practices acts of racial restriction because of requirements of religion. Such a problem may never arise; and if it ever does arise, it will have to be considered 
When racial discrimination is not religiously dictated, the only possible source of affirmative constitutional protection is the first amendment freedom of association. But the Norwood Court, in declaring racial discrimination by schools that received textbooks from the state to be violative of the equal protection guarantee, refused to afford affirmative constitutional protection to racial discrimination in the name of freedom of association: "Invidious private discrimination may be characterized as a form of exercising freedom of association protected by the First Amendment, but it has never been accorded affirmative constitutional protections." 141 The McGlotten Court, by requiring withdrawal of a government benefit on the basis of the racial practices of a nonreligious entity, was in accord with the Supreme Court in Norwood.

\section{Public Function}

When a private entity becomes engaged in a "public" function, countervailing considerations of privateness are rendered less significant, and constitutional restrictions should be more readily applied. The concept of public function is not a clearly defined one, but the Supreme Court has found it useful in justifying the application of the first and fourteenth amendments to a variety of situations - the conduct by a political party of primary elections, ${ }^{142}$ the regulation of the distribution of religious literature in a company-owned town, ${ }^{143}$ the regulation of union picketing in a shopping center, ${ }^{144}$ and racial discrimination in the operation of a park. ${ }^{145}$ In Burton, the Supreme Court observed that the garage building in which the restaurant was located was dedicated "[a]s an entity" "to 'public uses' in performance of the [Parking] Authority's 'essential governmental functions'."146 And in Moose Lodge, the Court's finding of no state

in the light of the particular facts and issues presented, and in light of the established rule ... that the law may prohibit an individual from taking certain action even though his religion commands or prescribes them.

Id. at 1169. A stronger statement along these lines was offered by Justice White in his dissenting opinion in Lemon v. Kurtzman, 403 U.S. 602, 671 n.2 (1971):

As a postscript I should note that both the federal and state cases are decided on specified Establishment Clause considerations, without reaching the questions that would be presented if the evidence in any of these cases showed that any of the involved schools restricted entry on racial or religious grounds or required all students gaining admission to receive instruction in the tenets of a particular faith. For myself, if such proof were made, the legislation would to that extent be unconstitutional.

14193 S. Ct. 2804, 2813 (1973).

${ }^{142}$ Smith v. Allwright, 321 U.S. 649 (1944).

${ }^{143}$ Marsh v. Alabama, 326 U.S. 501 (1946).

144. Amalgamated Food Employees Union v. Logan Valley Plaza, 391 U.S. 308 (1968).

${ }_{145}$ Evans v. Newton, 382 U.S. 296 (1966).

146365 U.S. at 723 . 
action was based in part upon the lack of any public function performed by the fraternal order. ${ }^{147}$

A few recent lower federal court cases demonstrate how the public function theory can be utilized to apply constitutional restrictions to a wide variety of private conduct. In Eaton v. Board of Managers of James Walker Memorial Hospital, ${ }^{148}$ the Fourth Circuit found no state action in the conduct of a hospital which received only $4 \frac{1}{2} \%$ of its budget from the government. Six years later, the court reversed its stand in Eaton v. Grubbs, ${ }^{149}$ a decision involving the same hospital. In discussing the reasons for abandoning its previous holding, the court concluded that "most importantly, the first Eaton case did not consider the argument now being made that the 'private' hospital is fulfilling the function of the state." ${ }^{150}$ In McQueen v. Druker, ${ }^{151}$ a private landlord who had purchased land from a city redevelopment authority, subject to many restrictions imposed by the authority, was held to act subject to constitutional restrictions, on the theory that he was assisting the state in realizing its goal of providing low- and moderate-income housing for those displaced by redevelopment. In analyzing the public function performed by the private landlord, the court stated: "Here the function, while perhaps not so traditionally governmental as parks, fire or police services, or libraries, is today one of the major concerns of most cities of substantial size."152 In United States $v$. Barr, ${ }^{153}$ private persons who acted as process servers pursuant to a New York statute were held to be within the ambit of the fourteenth amendment. The court reasoned that nonofficial process servers "perform a function of the sheriff, a public officer, when serving a summons and complaint under the statutory authorization." ${ }^{154}$ In DeCarlo v. Joseph Horne $\mathcal{E}^{3}$ Co. ${ }^{155}$ a private detective who made an arrest under the Pennsylvania Professional Thieves Act was found to have acted in the capacity of a police officer, and under color of law. In Colon v. Tompkins Square Neighbors, Inc., ${ }^{156}$ a private managing corporation of urban redevelopment apartments that benefited from tax exemptions as well as other government

${ }^{147}$ Justice Rehnquist emphasized that the Moose Lodge, by serving liquor at a private bar on its own premises, was not "located and operated in such surroundings that although private in name, it discharges a function or performs a service that would otherwise in all likelihood be performed by the State." 407 U.S. at 175 .

148261 F.2d 521 (4th Cir. 1958).

149329 F.2d 710 (4th Cir. 1964) (en banc).

150 Id. at $712-13$.

151438 F.2d 781 (1st Cir. 1971).

152 Id. at 784 .

153295 F. Supp. 889 (S.D.N.Y. 1969).

${ }^{154}$ Id. at 891 . A similar result was reached in United States v. Brand Jewelers, Inc.,

318 F. Supp. 1293, 1299 (S.D.N.Y. 1970).

155251 F. Supp. 935 (W.D. Pa. 1966).

156294 F. Supp. 134, 137-38 (S.D.N.Y. 1968). A similar conclusion was reached in Male v. Crossroads Assoc., 469 F.2d 616, 620-22 (2d Cir. 1972). 
financial aid, and was under considerable government control, was ruled to be bound by the fourteenth amendment.

The Moose Lodge and McGlotten cases can be distinguished from each other on the basis of the public function concept. McGlotten dealt with charitable tax incentives to fraternal orders-government involvement with private conduct which can be characterized as designed to induce private entities to undertake a public function. As the McGlotten court noted, charitable tax incentives have traditionally been defended on the ground that by allowing deductions for charitable contributions and exemptions for charitable organizations, "the Government relieves itself of the burden of meeting public needs which in the absence of charitable activity would fall on the shoulders of the Government." ${ }^{157}$ Moose Lodge, on the other hand, involved a private fraternal order licensed by the government to distribute alcohol. While the operation of a private bar by a private organization on its own premises cannot be classified as a function or service which the State would undertake in the absence of private fraternal orders, the distribution of charitable funds which are partially made up of government tax dollars can be viewed as delegation of a public function by the government to a private organization. It will become evident in the concluding section of this Comment, in which the principles set forth in this section are applied to various tax provisions, that the concept of public function is a crucial one in determining whether various tax incentives give rise to state action.

\section{The Nature of the Alleged Constitutional Violation}

Both existing case law and policy considerations suggest that different degees of government involvement are necessary to activate different constitutional restrictions-more specifically, that a lesser degree of government involvement suffices to activate the equal protection guarantee than is required to activate due process safeguards or the establishment of religion clause. One of the first cases to explicitly suggest the existence of such varying standards was Bright $v$. Isenbarger, ${ }^{158}$ in which two students brought a civil rights action seeking readmission to a parochial school after they had been expelled. In holding that the school, which was the beneficiary of a real property tax exemption, had not dismissed the students "under color of law," the district court stated:

Although no court has held that a different (less demanding) standard of what constitutes "sufficient" state

158314 F. Supp. 1382 (N.D. Ind. 1970), affd, 445 F.2d 412 (7th Cir. 1971). 
involvement is applicable where there are allegations of racial discrimination, the fact that only a handful of the successful "state action" cases have not involved challenges to racial discrimination and the considerations of diversity and pluralism suggest this possibility ... ${ }^{159}$

The principle that different degrees of government involvement are required to activate the due process and equal protection clauses was endorsed by a district court in another tax incentive case, Pitts v. Department of Revenue: "[A] different standard must be applied to ascertain state action in cases involving equal protection than in cases involving other rights." $160^{\circ}$ Judge Friendly recently expressed approval of a dual approach to state action in Grafton v. Brooklyn Law School:

while a grant or other index of state involvement may be impermissible when it "fosters or encourages" discrimination on the basis of race, the same limited involvement may not rise to the level of "state action" when the action in question is alleged to affront other constitutional rights. ${ }^{161}$

At first glance, the assertion that the same facts could give rise to a finding of state action for purposes of the equal protection clause but no state action for purposes of the due process clause might seem disturbing. But there are cờmpelling historical and policy considerations which justify this result. To the extent that equal protection claims involve racial discrimination and are made under the fourteenth amendment, the result is supported by the prevalent historical interpretation of the fourteenth amendment. That amendment was adopted primarily to counteract the forces of racism after the Civil War, and did not contemplate the extension of constitutional safeguards outside the field of racial discrimination. ${ }^{162}$ It is reasonable, therefore, to apply the amendment more stringently in cases involving racial discrimination than in other cases.

There is also a persuasive policy consideration weighing against the extension of due process safeguards to all cases to which the equal protection guarantee would extend. Every day, organizations with government ties make countless private decisions that affect individuals' property, employment and affiliations. If aggrieved individuals were entitled to notice, hearing and access to counsel before these decisions were made, the

${ }^{159} I d$. at 1394.

${ }_{160} 333$ F. Supp. 662 , 668 (E.D. Wis. 1971).

161478 F.2d II37, 1142 (2d Cir. I973). (1968).

${ }^{162}$ See Developments in the Law-Academic Freedom, 81 Harv. L. Rev. 1045, 1062 
ability of private entities to conduct their affairs smoothly and efficiently would be severely hampered.

A framework for the application of constitutional restrictions to government involvement should distinguish equal protection claims not only from due process claims, but also from claims brought under the establishment of religion clause. The Supreme Court indicated in Norwood that the constitutional prohibition imposed upon government assistance to private activity by the equal protection clause is more stringent than the prohibition commanded by the religion clauses. In deciding that granting free textbooks to private racially discriminatory schools violated the equal protection clause, the Court distinguished Board of Education v. Allen, ${ }^{163}$ in which the Court had upheld the constitutionality of a similar textbook program against an establishment of religion claim. A more stringent prohibition was found to reside in the equal protection clause because

the transcendent value of free religious exercise in our constitutional scheme leaves room for "play in the joints" to the extent of cautiously delineated secular governmental assistance to religious schools, despite the fact that such assistance touches on the conflicting values of the Establishment Clause by indirectly benefiting the religious schools and their sponsors.

In contrast, although the Constitution does not proscribe private bias, it places no value on discrimination as it does on the values inherent in the Free Exercise Clause. ${ }^{164}$

In other words, the Court found nothing in the racial discrimination context to create tension with the equal protection clause in the way that the free exercise clause creates tension with the establishment clause. Pitts $v$. Department of Revenue, ${ }^{165}$ Falkenstein $v$. Department of Revenue, ${ }^{166}$ and $M c$ Glotten ${ }^{167}$ applied this principle to the field of tax incentives before it was formally set forth in Norwood, in order to distinguish the Supreme Court holding in Walz v. Tax Commission. ${ }^{168}$ In Walz, the Court held that granting a real propery tax exemption to a religious organization was not sufficient to violate the establishment clause. McGlotten presented the clearest articulation of the principle later set forth in Norwood:

Defendant's reliance on Walz v. Tax Commission .. . for the proposition that tax exemptions provide

163392 U.S. 236 (1968).

16493 S. C. at 2813 .

165333 F. Supp. 662, 665-67 (E.D. Wis. 1971).

166350 F. Supp. 887, 889 (D. Ore. 1972).

167338 F. Supp. at 459 n.58.

168397 U.S. 664 (1970). 
insufficient Government involvement to violate the Constitution is misplaced. The holding in Walz was that exemption of church property from state property tax did not violate the First Amendment Establishment Clause. As such, it was premised on historical considerations peculiar to the First Amendment:

Few concepts are more deeply imbedded in the fabric of our national life, beginning with pre-Revolutionary colonial times, than for the government to exercise at the very least this kind of benevolent neutrality toward churches and religious exercise generally....

The history of the Fourteenth Amendment leads in exactly the opposite direction. It was designed explicitly to deal with the cancer of racial discrimination and a strict rather than benevolent neutrality is required on the part of Government. ${ }^{169}$

The Norwood decision seemingly removes $W a l z$ as an obstacle to the conclusion that tax incentives are capable of violating the equal protection clause. But the sweeping language of $W a l z$ may remain of some significance to cases involving establishment claims against tax incentives: "The grant of a tax exemption is not sponsorship since the government does not transfer part of its revenue to churches but simply abstains from demanding that the church support the state."170 By this language, the Court appears to have both rejected the functional equivalence theory and held that tax exemptions are of less constitutional significance as a form of government involvement than direct benefits. But the barrier that the Walz Court thereby erected to the "constitutionalization" of tax incentives was seemingly removed by the Court' holding in Griffin and Nyquist. ${ }^{171}$ It is difficult to assess how much of the Walz holding remains intact. The majority opinion in Nyquist devoted considerable effort to distinguishing Walz on three bases. ${ }^{172}$ First, the New York property tax exemption in Walz had been tolerated and approved since colonial times, while there was no historical precedent for the specific tax benefit in Nyquist. Second, the property tax exemptions were viewed as government attempts to neutralize the "hostility" inherent in the taxation process by minimizing fiscal contact, while the "special" tax benefits in Nyquist were not "neutral" but designed to advance religion. And third, the prop-

$169338 \mathrm{~F}$. Supp. at $459 \mathrm{n} .58$ (citations omitted).

$\overrightarrow{170} 397$ U.S. at 675 .

171 See text accompanying notes 53-57 supra.

17293 S. Ct. at 2975-76. 
erty tax exemptions were aimed at a wide range of recipients, while "special" tax benefits flowed primarily to the parents of children attending sectarian schools.

In light of Griffin and Nyquist, it is likely that the language in Walz rejecting the notion that tax incentives can be either economic or constitutional equivalents of direct grants has lost its effect. But whatever is left of Walz, the rationale of Norwood precludes its transplantation into the realm of equal protection.

\section{A Constitutional Analysis Of Tax Incentives}

\section{A. The Necessity for Constitutional Examination of Tax Benefits}

If, as we have seen, direct government expenditures and tax benefits confer functionally equivalent economic subsidies upon otherwise private entities, it becomes readily apparent that the constitutional restrictions which have traditionally been applied to other forms of government involvement with private conduct, ${ }^{173}$ including direct expenditures, should be applied to tax benefits as well. The allocation of governmental resources achieved through the use of tax benefits has a significant impact upon private activity. ${ }^{174}$ This enormous and heretofore virtually unchecked leverage ${ }^{175}$ should be exercised only within the

${ }^{173}$ See text accompanying notes 62-67 supra.

${ }^{174}$ See note 220 infra.

${ }^{175}$ See Green v. Connally, 330 F. Supp. 1150 (D.D.C.), affd mem. sub nom. Coit v. Green, 404 U.S. 997 (1971). Judge Leventhal explicitly avoided the constitutional issue, basing his decision upon interpretation of the Internal Revenue Code.

Several nonconstitutional grounds exist for challenging tax incentives. It would be possible for the legislature to pass a statute denying tax incentives or other government benefits to racially discriminatory private entities. The state of Maine followed this approach, prohibiting any holder of a liquor license from discriminating on the basis of race, religion or national origin. This statute was upheld by the highest state court in the face of a first amendment claim of freedom of association. B.P.O.E. Lodge No. $2043 \mathrm{v}$. Ingraham, 297 A.2d 607 (Me. 1972), cert. denied, 93 S. Ct. 1893 (1973). Although this legislative technique is useful in the context of racial discrimination, it is doubtful that it could be used to deny tax incentives to racially nondiscriminatory religious organizations. Under the entanglement analysis in Walz, 397 U.S. at 674, religious organizations have an arguable constitutional right to some tax exemptions under the first amendment freedom of religious exercise. See text accompanying notes 163-72 supra. Countervailing forces of free exercise and free association may arise in all of the nonconstitutional avenues to challenging tax incentives considered herein. In any event, the statutory approach which Bittker and Kaufman criticize in Taxes and Civil Rights, supra note 7, at 86, because they feel that the social costs of government control may be too high, has been hailed as one primary motivating factor behind the recent desegregation of the Benevolent and Protective Order of Elks. Philadelphia Inquirer, Jul. 20, 1973, $\S \mathrm{A}$, at 3, col. 3 .

A second nonconstitutional approach which has been successful in a rather limited context is the self-imposed administrative policy of the Internal Revenue Service, pursuant to which discriminatory private schools are ineligible for tax incentives. See Rev. Rul. 71-447, 1971-2 Cum. Bull. 230 (ruling that "charitable," as used in the Code, has to be read in terms of the everchanging common law concept of charity; based upon attitudes of present society and federal policy, a segregated school is not charitable). This appears to be the only instance of administrative self-restraint attempted to date.

Another nonconstitutional alternative which has been adopted by several courts, 
parameters of the Constitution. A contrary conclusion would not only be arbitrary and irrational, but would encourage legislatures to achieve through the use of tax benefits ends known to be constitutionally impermissible if sought through a direct expenditure scheme, circumventing the spirit of the Constitution. The application of constitutional restraints to tax benefits will not necessarily affect the allocation of theses benefits in the same manner or to the same extent as it affects the allocation of direct government expenditures, but tax benefits must not be permitted to remain free of constitutional examination.

It is incontrovertible that the constitutionalization of the tax laws will increase their complexity and difficulty of administration. Significant additional burdens may be placed upon the agencies charged with that administration. Undoubtedly those agencies would become obligated to monitor the conduct of the recipients of tax benefits to a greater extent than is presently their practice. As significant as these additional burdens may be, administrative inconvenience is an insufficient rationale to justify the abrogation of constitutional rights. ${ }^{176} \mathrm{~A}$ difference in the difficulty of monitoring the conduct of the recipients of government largesse between economically equivalent programs should not be permitted to become a distinction of constitutional magnitude.

The authors of Taxes and Civil Rights have suggested an additional reason, as a matter of policy, that the Internal Revenue Code should not be subjected to the rigors of constitu-

including the district court in McGlotten, is embodied in $\S 601$ of the Civil Rights Act of 1964,42 U.S.C. $\$ 2000 \mathrm{~d}(1970)$, which provides that "[n]o person in the United States shall, on the ground of race, color, or national origin, be excluded from participation in, be denied the benefits of, or be subjected to discrimination under any program or activity receiving Federal financial assistance." However, it is not clear that tax incentives constitute "Federal financial assistance" under $\$ 601$. See Taxes and Civil Rights, supra note 7 , at 79-85. The Civil Rights Act of 1964 is inapplicable to state tax incentives. State civil rights statutes present an additional alternative. Pennsylvania's public accommodation statute was construed to prohibit private fraternal orders from discriminating in the distribution of alcoholic beverages. Commonwealth v. Loyal Order of Moose, $448 \mathrm{~Pa}$. 451,294 A.2d 594 (1972). This decision was also cited as contributing to the recent decision of the Benevolent and Protective Order of Elks to desegregate. Philadelphia Inquirer, Jul. 20,1973, § A, at 3, col. 3 . A final possibility is a construction of the laws granting tax incentives which renders discriminatory entities ineligible. But it is far from clear that such an argument is tenable. See Taxes and Civil Rights, supra note 7, at 74-79.

${ }_{176}$ Stanley v. Illinois, 405 U.S. 645, 656 (1972), cited in United States Dep't of Agriculture v. Murry, 93 S. Ct. 2832, 2835 (1973):

The establishment of prompt efficacious procedures to achieve legitimate state ends is a proper state interest worthy of cognizance in constitutional adjudication. But the Constitution recognizes higher values than speed and efficiency. Indeed, one might fairly say of the Bill of Rights in general, and the Due Process Clause in particular, that they were designed to protect the fragile values of a vulnerable citizen from the overbearing concern for efficiency and efficacy that may characterize praiseworthy government officials no less, and perhaps more, than mediocre ones.

Another answer to the problem of administrative inconvenience is that the Internal Revenue Service seems to have survived the impact of its self-imposed regulation denying tax incentives to racially discriminatory private schools. This serves as an excellent model for expanding the auditing function of tax agencies. 
tional restraint. They fear that if the theory of McGlotten is adopted all tax benefits necessarily will be subjected to constitutional limitations. ${ }^{177}$ Bittker and Kaufman argue that tax benefits are ubiquitous and virtually indistinguishable from each other. Therefore, once tax benefits have been constitutionalized under the $M c$ Glotten analysis, all tax benefits regardless of their differences in purpose and impact will suffer the same fate.

If this conclusion were valid, it would certainly militate against constitutional scrutiny of tax incentives. Examination of the history of constitutional adjudication regarding government involvement with private activity will, however, allay this fear. Government involvement of various types has been held insufficient to bring otherwise private conduct within the proscription of the fourteenth amendment. ${ }^{178}$ Grants, ${ }^{179}$ charters, ${ }^{180}$ leasing agreements, ${ }^{181}$ textbooks, ${ }^{182}$ liquor licenses ${ }^{183}$ and the tax free status of government bonds ${ }^{184}$ have failed to activate constitutional restrictions. If courts were able to draw the line between the permissible and the impermissible in those areas, there is no reason to anticipate that all tax benefits will be held to impose constitutional prohibitions upon their recipients. The constitutional analysis developed in the previous section provides a flexible, comprehensive framework within which to constitutionalize the Internal Revenue Code, as well as tax incentives at the state and local government levels. ${ }^{185}$

\section{B. A Normative Concept of Income; The Distinction Between Tax Incentives and Tax Benefits}

The distinction between tax benefits and tax incentives ${ }^{186}$ must be premised upon a workable and generally acceptable

177 Taxes and Civil Rights, supra note 7 , at 86.

178 See text accompanying notes 62-172 supra.

${ }_{179}$ Tilton v. Richardson, 403 U.S. 672 (1971) (involving the first amendment religion clauses); Everson v. Board of Educ., 330 U.S. 1 (1947) (involving the first amendment establishment of religion clause); Bradfield v. Roberts, 175 U.S. 291 (1899) (involving first amendment establishment of religion clause). For several examples in the realm of the equal protection guarantee, see text accompanying notes 85-91 supra.

180 In Stearns v. Veterans of Foreign Wars, 353 F. Supp. 473 (D.D.C. 1972) (mem.) the court held that the mere grant of a congressional charter, absent discriminatory language in the charter itself, was not significant government involvement with the sexually discriminatory membership clause of the Veterans of Foreign Wars.

${ }_{181}$ In Hunt v. McNair, 93 S. C. 2868 (1973), the Supreme Court held that leasing portions of a college campus by a state entity to a religious organization did not violate the establishment clause.

${ }_{182}$ A New York statute providing for the gratuitous lending of books by the state to students in both public and parochial schools was upheld by the Supreme Court in Board of Educ. v. Allen, 392 U.S. 236 (1968).

${ }_{183}$ Moose Lodge No. 107 v. Irvis, 407 U.S. 163 (1972).

184 Hunt v. McNair, 93 S. Ct. 2868 (1973).

${ }^{185}$ See notes 62-172 supra \& accompanying text.

${ }^{186}$ Compare the definition of "tax benefit," note 26 supra, with the definition of "tax incentive," note 1 supra. 
definition of income. There is near-consensus among tax scholars regarding the desirability of constructing a normative model of income. ${ }^{187}$ Many of those who advocate the tax expenditure theory do so in full awareness of the magnitude of the problems awaiting any attempt to arrive at a universally acceptable definition of income. ${ }^{188}$ Professor Bittker has, however, expressed serious misgivings about both the desirability and the utility of any such model, ${ }^{189}$ criticizing the HaigSimons definition with particular vigor. ${ }^{190}$ Although Taxes and Civil Rights contains no explicit criticism of the quest for a

${ }^{187}$ For tax scholars who are reluctant to accept the normative income tax model, see Slater, Tax Incentives of State and Local Governments, in TAX INSTITUTE OF AMERICA, TAX INCENTIVEs (1971), and Warren, Krattenmaker \& Snyder, Property Tax Exemptions for Charitable, Educational, Religious and Governmental Institutions in Connecticut, 4 ConN. L. REv. I81 (1971). Among those scholars who seem willing to work towards such a normative model are: C. Kahn, Personal Deductions in the Federal Income Tax 88 (1960); Aaron, supra note 28; Blum, supra note 2; Brannon, $A$ Requiem for the Investment Tax Credit, in Tax Institute of America, Tax Incentives (1971); Taubman \& Rasche, supra note 28.

A pioneer treatment of the concept of a normative tax model is Wolfman, Federal Tax Policy and the Support of Science, 114 U. PA. L. REv. 171, 173-74 (1965):

Reference to a tax provision as "preferential" or "special" does not connote opposition to the social or economic objective which Congress has used the tax law to support. It does mean the provision deviates from a norm. Implicit in the reference is the idea that the income tax has an essential integrity; that there is a fundamental standard for determining the tax base and the applicable rates....

The concept of "special relief" or "preference" means to me a deviation from a relatively neutral net income base or the application of rates which are tailored according to the source from which income is derived or the purpose for which it is spent. . . It does mean there is a departure from standard.

${ }^{188}$ See Aaron, Inventory of Existent Tax Incentives-Federal, in TAX INSTITUTE of America, Tax InCENTIVes 39 (1971); Blum, Federal Income Tax Reform-Twenty Questions, 41 TAXES 672, 679 (1963); Surrey, Tax Incentives-Conceptual Criteria for Identification and Comparison with Direct Government Expenditures, in TAX INSTITUTE OF AMERICA, TAX INCENTIVES 3, 5 (1971).

${ }_{189}$ Taxes and Civil Rights, supra note 7, at 63.

190 The authors of Taxes and Civil Rights assert that for "tax commentators who believe that this distinction [between tax incentives and tax provisions merely defining income] is fruitful, the standard is the Haig-Simons definition of income." Id. 63. Briefly stated, the Haig-Simons definition provides: "Personal income may be defined as the algebraic sum of (1) the market value of rights exercised in consumption and (2) the change in the value of the store of property rights between the beginning and end of the period in question." H. Simons, Personal Income Taxation 61-62 (1938), cited in Taxes and Civil Rights, supra note 7, at 64. In light of Professor Bittker's previous exchange of articles with Professors Surrey and Hellmuth, and the published statement of other advocates of the tax expenditure theory, it is quite difficult to understand why he maintains such a position. These articles are, in order of publication: Bittker, Accounting for Federal "Tax Subsidies" in the National Budget, 22 NAT. TAX J. 244 (1969); Surrey \& Hellmuth, The Tax Expenditure Budget-Response to Professor Bitter, 22 NAT. TAX J. 528 (1969); Bittker, The Tax Expenditure Budget-A Reply to Professors Surrey $\mathcal{E}^{2}$ Hellmuth, 22 NAT. TAX J. 538 (1969). An example of a statement by another commentator may be found in Aaron, What is a Comprehensive Tax Base Anyway?, 22 NAT. TAX J. 543, 547 (1969). The proponents of the tax expenditure theory themselves disagree over the proper definition of income, although all of course agree that some definition is possible and desirable. Surrey disagrees with some portions of the Treasury Tax Expenditure Budget. See Surrey, Federal Income Tax Reform: The Varied Approaches Necessary to Replace Tax Expenditures with Direct Governmental Assistance, 84 HARv. L. Rev. 352, 384 n.58 (1970). Surrey also has points of disagreement with Aaron. Id. $365 \mathrm{n} .17$. Aaron proposes his own definition of tax incentives which is at odds with the Treasury Department s. See Aaron, Inventory of Existing Tax Incentives-Federal, in TAX Instirute of AMERICA, TAX IncenTIVES (1971). 
normative tax model, Professor Bittker has voiced his dissatisfaction on previous occasions:"191 "I cannot discern behind the tangle of rules that make up the income averaging and net operating loss provisions an 'ideal,' 'model,' or 'correct approach'-modifications of which constitute 'tax expenditures." "192

This position is, however, a minority view. ${ }^{193}$ In fact, one commentator who agrees with the assertion in Taxes and Civil Rights that tax provisions benefiting fraternal orders are not tax incentives but only tax benefits disagrees with Bittker regarding the utility of a normative model of income: "[I]n the end it is useful to speak in terms of an ideal income tax and to evaluate departures from the ideal as tax expenditures whose purposes, not being reflected in the ideal, must be extraneous to those of the tax. ${ }^{194}$ Certainly the misgivings expressed regarding the efficacy and utility of a normative tax model fail to present either a persuasive case for the total rejection of the theory that income-defining tax provisions can be distinguished from tax incentives, or a compelling argument against the application of constitutional restrictions to the government subsidy conferred by tax benefits. Thus, it will be assumed that a generally acceptable normative model of income can be derived.

A normative concept of income is essential in distinguishing tax incentives from the more general class of tax benefits. Tax benefits include all tax provisions which confer benefits upon taxpayers, encompassing deductions, deferrals, credits and exemptions. Several tax benefits exist not to induce private activity, however, but to provide a more accurate measure of income or property value. Such provisions have been enacted for the purwrote:

${ }^{10}$ In Churches, Taxes and the Consitution, 78 YaLE L.J. 128̄5, 1296 (1969), Bittker

[T] tax; unless we can see the whole, we cannot know if something has been carved out. Unfortunately for any hope of readily identifying "exemptions," however, "ideal" taxes are hard to come by, even if our models are academic projects rather than statutes shaped by the interaction between relentless lobbyists and harried legislators: . . The anti-exemption case, then, suffers from a crisis of definition.

In $A$ "Comprehensive Tax Base" as a Goal of Income Tax Reform, 80 HaRv. L. REv. 925, 985 (1967), Bittker wrote:

There are many problem areas in which the search for "preferences" is doomed to fail because we cannot confidently say which provisions are "rules" and which are "exceptions." ... The central source of difficulty is the fact that the income tax structure cannot be discovered, but must be constructed; it is the final result of a multitude of debatable judgments. ... When we turn to the field of income taxation . . . we do not begin with a consensus on the meaning of income, but with a myriad of arguments about what should be taxed, when, and to whom.

${ }_{192}$ Bittker, Accounting for Federal "Tax Subsidies" in the National Budget, 22 NAT. TAx J. 244, 258 (1969).

${ }_{193}$ See sources cited note 187 supra. (1972).

194 Andrews, Personal Deductions in an Ideal Income Tax, 86 Harv. L. Rev. 309,312 
pose of facilitating the operation of the tax laws or aiding in the identification of income and should not be considered to constitute significant government involvement with otherwise private activity. Thus, due to their very nature, those provisions whose purpose is to define income or property value should not be subjected to constitutional scrutiny. ${ }^{195}$ Tax incentives, on the

${ }^{195} \mathrm{~A}$ loose analogy may usefully be drawn to the necessities-of-life distinction recently developed and utilized by the Supreme Court in both first and fourteenth amendment contexts. The necessities-of-life distinction presumes that there are several government activities which, although they have the indirect effect of subsidizing private conduct, exist primarily to facilitate the ongoing operation and maintenance of a governmental structure. Such government activities were characterized as "necessities of life" by Mr. Justice Rehnquist in Moose Lodge No. 107 v. Irvis, 407 U.S. 163 (1972), and should be distinguished from those government activities which are capable of activating constitutional restrictions:

The Court has never held, of course, that discrimination by an otherwise private entity would be violative of the Equal Protection Clause if the private entity receives any sort of benefit or service at all from the State, or if it is subject to state regulation in any degree whatever. Since state-furnished services include such necessities of life as electricity, water, and police and fire protection, such a holding would utterly emasculate the distinction between private as distinguished from state conduct set forth in The Civil Rights Cases .... [W] [Were the impetus for the discrimination is private, the State must have "significantly involved itself with invidious discriminations," in order for the discriminatory action to fall within the ambit of the constitutional prohibition.

Id. at 173 (emphasis added). The Court reiterated the distinction in the more recent case of Norwood v. Harrison, 93 S. Ct. 2804 (1973), where a Mississippi statute enacted prior to the Court's decision in Brown v. Board of Educ., 347 U.S. 483 (1954), provided free textbooks to students in public and private schools. The statute was invalidated to the extent that it provided assistance to students in private racially discriminatory schools:

We do not suggest that a State violates its constitutional duty merely because it has provided any form of state service that benefits private schools .... . [Textbooks] are to be distinguished from generalized services government might provide to schools in common with others. Moreover, the textbooks provided to private school students by the State in this case [are not] ... "such necessities of life as electricity, water, and police and fire protection."

93 S. Ct. at $2810-11$.

In the context of the first amendment religion clauses, the Court in Lemon $v$. Kurtzman, 403 U.S. 602 (1971), drew a similar exception for government activity which is so "generalized" as to be incapable of activating constitutional restrictions:

Our prior holdings do not call for total separation between church and state; total separation is not possible in an absolute sense. Some relationship between government and religious organizations is inevitable. . . . Fire inspections, and building and zoning regulations, and state requirements under compulsory school-attendance laws are examples of necessary and permissible contacts.

Id. at 614 .

The implicit assumption of the necessities-of-life distinction is that all private entities are entitled to a basic minimum package of government-furnished services and benefits, regardless of their beliefs, policies or actions. See notes 95-103 supra \& accompanying text. Building permits, driver's licenses, sewer service, sidewalks, streets, parks, postal service, utilities, liquor licenses and fire and police protection should be among the benefits supplied to private entities without regard to their discriminatory activities. But when a government-furnished service or benefit transcends this basic category, the nature of the relationship thus engendered between the government and the private entity should be evaluated in light of constitutional restrictions. The necessities-of-life distinction is a threshold barrier to constitutional review, which automatically exempts certain government involvement with private conduct from constitutional scrutiny. Although the distinction suffers from definitional difficulties, its basic point is clear: minimum governmental services essential to the ongoing governmental structure may be provided neutrally to all private entities regardless of their policies.

The exception provided for those tax benefits which are designed to aid the 
other hand, include those tax benefits which are intended to induce private activity and not to aid in the measurement of income or property value. ${ }^{196}$ Tax incentives must therefore be subjected at least initially to constitutional analysis, although not all will be found to activate constitutional restrictions. ${ }^{197}$

In this context, difficulties inherent in the definition of income and in the decision as to which tax benefits are true income or property value defining provisions become significant indeed. Many provisions exist in tax codes for obscure reasons and the determination whether a particular provision is truly income defining can on occasion be virtually impossible. Despite the difficulties that inhere in reaching a generally acceptable normative concept of income, some benefits are clearly intended to define income and not to encourage particular conduct. One generally recognized example is the business expense deduction. ${ }^{198}$ While this tax benefit subsidizes private activity, its primary function is to enable the government to measure more accurately the net income of a business. By granting business expense deductions, the government takes into account the expenses reasonably incurred in the course of generating income, for the purpose of making a realistic computation of a business' taxable income. Judge Bazelon, speaking for the court in McGlotten, noted other straightforward examples of income defining provisions in the Internal Revenue Code: section 172, relating to net operating loss carryovers and carrybacks, and sections 1301-05; dealing with income averaging. ${ }^{199}$

Other provisions, however, are not as evidently intended to define income or measure property. In ascertaining the nature of such provisions one area of great difficulty is the determination of the relative weight to be afforded legislative intent and economic effect. How significant should legislative intent be in determining whether a particular tax provision is related primarily to the measurement of income? If the legislative history is either silent or inconclusive regarding the purpose of a particular tax provision, what other factors should govern the determination? Should a provision which was clearly intended by the legislature to induce private activity automatically be classified as a tax incentive regardless of its practical economic effect? If the

measurement of income or property value is to some extent analogous. Although such structural provisions unquestionably do result in economic benefit to private entities, they are intended primarily to facilitate the operation of the tax laws. Like the basic minimum package of government services, they should not activate constitutional restrictions, regardless of the policies of their recipients. It is only tax incentives-those provisions which are primarily intended to induce private activity-which would be subjected to constitutional scrutiny.

${ }_{196}$ See note I supra.

197 See text accompanying notes 222-62 infra.

198 INT. REv. CoDE OF 1954 , § 162.

199338 F. Supp. at 457 n.44. 
distinction between tax incentives and other tax provisions for constitutional purposes were to rest solely upon legislative intent, would this approach contradict the Supreme Court's directive that motive should not be utilized as an index for violations of the equal protection clause? ${ }^{200}$ How should a tax provision be classified if the legislature enacted it for administrative convenience, but it continues in the code as an inducement to private activity? Arguably, the deduction for mortgage interest is just such a provision. ${ }^{201}$ If the actual effect exerted by such a tax provision is deemed to be an important factor in the determination, how should this effect be measured? The significance of these problems of intent can be demonstrated by an examination of the histories of the two tax benefits discussed in Taxes and Civil Rights, sections $170(\mathrm{c})(4)$ and 501(c)(8) of the Internal Revenue Code.

The legislative history of section $170(c)(4)$ leaves little doubt that the charitable gift deduction was intended by Congress to induce private activity-charitable contributions by taxpayers. Section $170(c)(4)$ 's predecessor was enacted during World War I at a time when public opinion feared that private philanthropic support of charities might be halted. ${ }^{202}$ It was introduced by Senator Hollis of New Hampshire, who advised that charitable gifts serve a public purpose and should be encouraged by Congress through the device of a tax deduction:

[F]or every dollar that a man contributes for these public charities ... the public gets 100 per cent; it is all devoted to that purpose. If it were undertaken to support such institutions through the Federal Government or local governments and the taxes were imposed for the amount they would only get the percentage . ... Instead of getting the full amount they would get a third or a quarter or a fifth. ${ }^{203}$

Twenty-one years later, a House Report acknowledged the benefit gained by the government from charitable deductions: "The Government is compensated for its loss of revenue by its relief from financial burdens which would otherwise have to be met by appropriations from public funds."204

\footnotetext{
${ }^{200}$ See text accompanying notes 118-22 supra.

201 INT. ReV. CODE OF 1954, \& 163.

202 Washington Post, Aug. 25, 1917, cited in 55 Cong. Rec. 6728 (1917):

This country can not abandon or impoverish the great structure of private charity and education that has been one of the most notable achievements of American civilization. Therefore with every additional dollar the Government finds it necessary to take in taxation it become increasingly necessary to accept the principle of the pending amendment and leave untaxed that part of every citizen's income which he may give voluntarily to the public good.

${ }^{203} 55$ CoNG. REC. 6728 (1917).

${ }^{204}$ H.R. REP. No. 1860 , 75th Cong., 3d Sess. 19 (1938), cited in 338 F. Supp. at 456.
} 
Although the legislative history of section 170(c)(4) provides a clear indication that Congress originally intended the section to encourage private charitable gifts, some tax scholars have suggested that section $170(\mathrm{c})(4)$ today exerts only a minimal effect on charitable giving. ${ }^{205}$ Positing that section $170(\mathrm{c})(4)$ has little influence upon the private activity which Congress intended to stimulate when it enacted the provision, should it nevertheless be considered a tax incentive? How can the incentive effect be quantified? And what result follows if it can be shown that the section has a partial but inconclusive incentive effect on private charitable giving?

The legislative history of section $501(\mathrm{c})(8)$ is less clear than that of section $170(\mathrm{c})(4)$. Bittker and Kaufman assert that Congress did not intend section 501(c)(8) to induce private activity, but rather that the income tax exemption for fraternal orders was originally drafted for administrative convenience. ${ }^{206}$

A close examination of the legislative history of section 501 (c)(8) reveals that the interpretation set forth in Taxes and Civil Rights is incomplete. Bittker and Kaufman choose the Revenue Act of $1913^{207}$ as the origin for their historical study of section 501(c)(8). ${ }^{208}$ But the roots of section 501(c)(8) stretch further back; most of the language of the exemption in the Revenue Act of 1913 is identical to a provision of the Act of $1909^{209}$ that exempted fraternal orders from an excise tax on corporations and other entities. ${ }^{210}$ Debate on the floor of the House merely intended to adopt the fraternal order exemption of 1909 with regard to income tax. ${ }^{211}$ Therefore the Act of 1909, not the Revenue Act of 1913, should be probed for evidence of congressional intent.

Senate debate over the 1909 Act indicates that the fraternal order exemption reflected congressional recognition of the charitable nature of such organizations. One question considered by the Senate was whether the Act, which by its language applied to "every insurance company," 12 was intended to apply to fraternal beneficiary companies. Senator Flint stated that the Act was intended to exempt from the excise tax those organizations "where the insurance is a mere incident to the other part of their

\footnotetext{
${ }^{205}$ See Taussig, Economic Aspects of the Personal Income Tax Treatment of Charitable Contributions, 20 NAT. TAX J. 1 (1967).

${ }^{206}$ Taxes and Civil Rights, supra note 7 , at 64-65.

207 Act of Oct. 3, 1913, ch. 16, 38 Stat. 114, 172, cited in J. Seidman, Seidman's Legrslative History OF FEDERAl. INCOME TAX LAws: 1938-1861, at 983-1007 (1938).

${ }^{208}$ Taxes and Civil Rights, supra note 7, at 65 n.40.

209 Act of Aug. 5, 1909, ch. 6, \& 38, 36 Stat. 11, 113.

$210 \mathrm{~J}$. SeIDMAN, supra note 207, at 1008.

21150 CoNG. REC. 509 (1913): "Paragraph G [which contained the fraternal order exemption] imposes a like normal tax upon the net profits, gains, or income of corporations without exemption. The provisions and administrative machinery of the present corporation-tax law [the Act of 1909] are, in the main, re-enacted."

$212 \mathrm{~J}$. Seidman, supra note 207, at 1009.
} 
work, which is fratermal and charitable."213 No consideration was given to whether those fraternal beneficiary companies were operating at a profit. The justification for their exemption was their charitable nature. The Conference Committee Report on the Revenue Act of $1913^{214}$ contains further evidence supporting the view that Congress exempted fraternal orders out of concern for their charitable nature, rather than a desire for administrative convenience. The report extended the exemption previously available to fraternal orders to "civic organizations operated exclusively for the promotion of social welfare." 215 Additionally, section 501(c)(3), ${ }^{216}$ which Bittker and Kaufman concede not to have been a product of congressional concern for administrative convenience, ${ }^{217}$ appeared in the same paragraph with the fraternal order exemption in the Act of 1909.218

The legislative history of section $501(\mathrm{c})(8)$ is inconclusive; it can be argued either that Congress intended the section as an incentive to private activity, or as an administrative convenience. Whatever the original legislative intent may have been, section $501(c)(8)$ is no longer explicable solely as administrative. The passive income of fraternal orders has grown substantially since 1909. For example, the Grand Lodge of the Benevolent and Protective Order of Elks of America in 1972 had a passive investment income of over $\$ 105,000 .^{219}$ Given the inconclusive nature of the legislative history, should the classification of section 501(c)(8) as a tax incentive depend upon an appraisal of its operative effect?

Some resolution of conflicting indicia of intent must be sought. Therefore it is suggested that when it is unclear from the face of the statute whether a tax benefit is an income defining

${ }^{213} 44$ CoNG. REc. 3938 (emphasis added).

${ }^{214}$ H.R. REP. No. 86, 63 d Cong., lst Sess. 26 (1913), cited in J. SeIdman, supra note 207 , at 1002 .

215 Id.

${ }^{216}$ INT. REv. CoDE of 1954, \& 501(c)(3): "Corporations, and any community chest, fund, or foundation, organized and operated exclusively for religious, charitable, scientific, testing for public safety, literary, or educational purposes . . . [are exempted under $\$ 501(a)]$."

${ }^{217}$ Taxes and Civil Rights, supra note 7, at 71.

218 . Serdman, supra note 207. as follows:

219 The passive investment income of the Grand Lodge for the past 5 fiscal years was

$$
\begin{aligned}
& 1968-\$ 74,782.79 \\
& 1969-\$ 79,864.40 \\
& 1970-\$ 95,577.63 \\
& 1971-\$ 102,502.81 \\
& 1972-\$ 105,172.29
\end{aligned}
$$

The passive investment of the Elks Magazine for the past 5 fiscal years was as follows: $1968-\$ 44,997.59$

$1969-\$ 63,322.98$

$1970-\$ 99,768.29$

$1971-\$ 97,596.03$

$1972-\$ 84,879.16$

Stipulation of Facts, McGlotten v. Shultz, Civ. No. 3377-70 (D.D.C. 1971). 
provision or a tax incentive, legislative history be consulted first; only if there is residual confusion need the operative effect be evaluated and quantified. Legislative history is demonstrably a dangerous morass, but all tax benefits, regardless of intent, produce an economic benefit for taxpayers. The practical problems related to the evaluation of operative incentive effect are even more significant than those inherent in the study of legislative history.

Despite the serious definitional difficulties inherent in formulating a normative model of income capable of distinguishing between tax incentives and income defining provisions, advocates of the tax expenditure theory have persisted in their attempts. Such difficulties do not require total abandonment of the concept of tax expenditures. Nor should they preclude constitutional review of those provisions which are generally considered unrelated to the measurement of income. The allocation of a government subsidy of such overwhelming proportions as that demonstrated in the Treasury Department's Tax Expenditure Budget $^{200}$ should be exempt from constitutional review only if it can be conclusively demonstrated that there is no possible method to identify any provision unrelated to the measurement of income or property value. As Henry Aaron suggests: "[N]o compendium of narrowly focused fiscal instruments such as the Tax-Expenditure Budget will be immune to the type of criticism advanced by Bittker. Theoretical sloppiness does not critically impair its practical value."221

\section{The Application of the Constitutional Framework to Tax Incentives}

Those tax benefits which can be distinguished as tax incentives should be analyzed to determine whether it is appropriate to subject their recipients to constitutional restrictions. Not all tax incentives will constitute state action sufficient to activate constitutional restrictions, but all must be subjected to constitutional scrutiny. The four-part inquiry developed in the preceding section provides a comphensive but flexible framework within which to conduct this analysis.

Sections $170(\mathrm{c})(4)$ and $501(\mathrm{c})(7),(8)$ of the Internal Revenue Code, ${ }^{222}$ the tax incentives discussed in Taxes and Civil Rights

${ }^{220}$ See notes 26-61 supra \& accompanying text.

221 Aaron, Inventory of Existant Tax Incentives-Federal, in TAX INSTITUTE of AMERICA, TAX INCENTIVES 45 (1971).

SEC. 170. CHARITABLE, ETC., CONTRIBUTIONS AND GIFTS.

(a) Allowance of Deduction.-

(1) GeNeral Rule-There shall be allowed as a deduction any charitable contribution (as defined in subsection (c)) payment of which is made within the 
and evaluated in $M c G l o t t e n$, provide excellent examples for this constitutional analysis. They will be probed in detail to discover whether they should activate constitutional restrictions. Additionally, several provisions chosen from the Treasury Department's Tax Expenditure Budget ${ }^{223}$ will be discussed, providing a range of examples which should adequately demonstrate the frequency with which tax incentives will be subjected to constitutional prohibitions.

It may be useful at this point to recapitulate briefly the four elements central to the constitutional analysis already developed:224 (1) the nature and degree of government involvement with the otherwise private entity; (2) the nexus between the government involvement and the challenged private activity; (3) the nature of the conduct engaged in by the private entity-that is, the privateness or the publicness of the conduct; and (4) the nature of the constitutional claim-that is, whether the conduct is challenged as a violation of the equal protection guarantee, the due process guarantee, or the first amendment religious guarantees. It is to be noted that, although all four elements will be relevant, the approach is flexible and the relative weight of each of the elements may vary with respect to different tax incentives.

taxable year. A charitable contribution shall be allowable as a deduction only if verified under regulations prescribed by the Secretary or his delegate.

(c) Charitable Contribution Defined.-For purposes of this section, the term "charitable contribution" means a contribution or gift to or for the use of -

(4) In the case of a contribution or gift by an individual, a domestic fraternal society, order, or association, operating under the lodge system, but only if such contribution or gift is to be used exclusively for religious, charitable, scientific, literary, or educational purposes, or for the prevention of cruelty to children or animals.

* * * *

SEC. 501. EXEMPTION FROM TAX ON CORPORATIONS, CERTAIN TRUSTS, ETC.

(a) Exemption From Taxation.-An organization described in subsection (c) or (d) or section 401 (a) shall be exempt from taxation under this subtitle unless such exemption is denied under section 502 or 503 .

(c) LIST OF EXEMPT ORGanizations.-The following organizations are referred to in subsection (a):

(7) Clubs organized and operated exclusively for pleasure, recreation, and other nonprofitable purposes, no part of the net earnings of which inures to the benefit of any private shareholder.

(8) Fraternal beneficiary societies, orders, or associations-

(A) operating under the lodge system or for the exclusive benefit of the members of a fraternity itself operating under the lodge system, and

(B) providing for the payment of life, sick, accident, or other benefits to the members of such society, order, or association or their dependents.

INT. REV. CODE OF 1954, $\$ \$ 170,501$.

${ }^{223}$ See text accompanying notes 26-61 supra.

${ }^{224}$ See text accompanying notes 62-172 supra. 
Sections 501(c)(7),(8) exempt nonprofit clubs and fraternal orders from income taxation. Section $170(\mathrm{c})(4)$, through the operation of section $170(\mathrm{a})(1)$, provides for the deductibility of contributions to such fraternal orders if the contributions are used for charitable puposes. ${ }^{225}$ Although the sections are not parellel and serve quite different purposes, they are analyzed concurrently for contrast, because the court in McGlotten dealt specifically with them, and because a ruling or verification is essential to eligibility under each.

The natural point of departure for the constitutional analysis of these provisions is an inquiry into the nature and degree of government involvement with the otherwise private recipients of the subsidies they confer. Government approval and control of the charitable tax exempt organizations will be discussed first.

Arguably, the granting of a charitable tax incentive places a government badge of approval on the conduct of the recipients of that incentive. Prospective donors tend to shun those organizations which have not been verified under section $170(a)(1)$ or ruled upon under section 501(c), gravitating toward organizations which offer assured deductibility. The Commissioner of Internal Revenue has acknowledged that government regulation has a channelling effect on charitable funds:

While all of this time is passing [before a section 501 (c) determination is issued], the organization is dormant for lack of contributions and those otherwise interested in its program lose their interest and move on to other organizations blessed with the Internal Revenue Service imprimatur . ...226

Kenneth Eliasberg has noted that "without a favorable Service ruling, it [would] be almost impossible to attract outside contributions."227 Private foundations have felt the practical effect of this channelling process, especially in the wake of the Tax Reform Act of 1969. ${ }^{228}$ The influence of the government on the

${ }^{225}$ See note 222 süpra.

226 Thrower, IRS is considering far reaching changes in ruling on exempt organizations, 34 * J. Taxation 168 (1971).

${ }^{227}$ Eliasberg, Exempt Organizations and Charitable Contributions: The Tax Reform Act of 1969-Sections 50I(c) and 170, 23 U. So. CAL. 1971 TAX INST. 357, 361 n.9.

${ }^{228}$ Ruth Chance, Executive Director of the Rosenberg Foundation, while discussing the effects of the 1969 Act on the relationship between foundations and grantees, spoke of increased monitoring of the activities of grantees by the donor foundations. Chance, Operational Effects, in TAX INSTITUTE of AMERICA, TAX IMPACTS ON PhILANTHROPY 103 (1972). Both she and Thomas H. Wright, Jr. of the Ford Foundation recommend requesting all potential grantees to furnish foundations with copies of their exemption rulings from the Internal Revenue Service. The Ford Foundation follows this procedure in every case, and also asks for a copy of the Form 4653 sent by prospective grantees to the Internal Revenue Service, plus any feedback from the Service regarding the Form 4653. See id. at 109; Wright, Grantee Selection and Supervision: Legal Requirements and Practical Problems, in 10 Conference on Charitable Foundations 127, 130, 134 (1971). 
allocation of charitable funds is so great the the Internal Revenue Service has proposed several reforms to expedite the process of securing a favorable ruling. ${ }^{229}$

Lower federal courts have acknowledged that a Service ruling can create the popular impression of government approval among the general public. The court in Green $v$. Kennedy ${ }^{230}$ took judicial notice of this effect in the context of contributions to racially discriminatory private schools, and the court in McGlotten held that "the government has marked certain organizations as 'Government Approved' with the result that such organizations may solicit funds from the general public on the basis of that approval." 231

This sense of government approval of private conduct may also arise from tax incentives granted on the state and local levels. The court in Falkenstein concluded that Oregon, by granting a charitable exemption, "places its stamp of approval on the Elks Lodge as an organization that furthers the legislative policy of the State."232

Although those organizations with positive determinations from the IRS can actively solicit funds with the Service determination underscored in their advertisements, tax scholars do not all agree that this necessarily connotes government approval of the organization or its activities to the public. ${ }^{233}$ Many may view this as signifying merely that the organization has successfully conquered the inevitable government red tape. Regardless of the

2:2y Thrower, supra note 226, at 168-70.

${ }^{230} 309 \mathrm{~F}$. Supp. at 1135 .

231338 F. Supp. at 456.

${ }^{232}$ Falkenstein v. Department of Revenue, 350 F. Supp. 887, 889 (D. Ore. 1972).

The IRS also publishes the Tentative Cumulative List of Organizations, a compilation of organizations, including fraternal orders, described in $\$ 170(c)$. Both Loyal Order of Moose Supreme Lodge of the World and Benevolent \& Protective Order of Elks Charity Fund are listed. One of Bittker's and Kaufman's arguments against the proposition that the government places its seal of approval upon fraternal orders by granting tax incentives is that "the Treasury's Cumulative List of Exempt Organizations, which is regularly consulted by taxpayers who want assurance that their contributions will be deductible [excludes] \& 501 (c)(7) fraternal orders." Taxes and Civil Rights, supra note 7, at 72 n.55. Acknowledging the importance of obtaining this listing, the Court of Appeals for the District of Columbia has written:

Because of the "tax breaks" attendant to contributions to corporations qualifying under $\$ 170(c)$ of the Code, qualification thereunder is a precious possession and removal from the Cumulative List, Organizations Described in Section 170(c) of the Internal Revenue Code of 1954 is a damaging-sometimes fatal-injury to the financial status of any "charitable" organization. Potential contributors with a minimum of business acumen are careful to get the most for their contributed dollar, and one certain way not to do so is to contribute to non- $\$ 170$ corporations.

“Americans United" Inc. v. Walters, Civ. No. 71-1299 at 12 (D.C. Cir., Jan. 11, 1973).

The affirmative use of Service rulings in fundraising campaigns by charitable organizations-particularly private segregated schools in the South-is well documented. See U.S. Comm's on Civil Rights, SoutherN School Desegregation-1966-67, at 142; Spratt, Federal Tax Exemption for Private Segregated Schools: The Crumbling Foundation, 12 WM. \& MARY L. Rev. 1, 3-4 (1970).

${ }^{233}$ See, Taussig, Economic Aspects of the Personal Income Tax Treatment of Charitable Contributions, 20 NAT. TAx J. I (1967). 
perceptions of the public, one point is clear: charitable tax incentives do not in fact necessarily bestow affirmative government approval upon the activities engaged in by the particular charitable organizations. Thus, despite judicial acknowledgement of the public impression conveyed government approval of charitable organizations, it seems that no firm conclusion may be drawn regarding the constitutional weight to be afforded government approval in an analysis of charitable tax incentives.

Very similar considerations emerge in an analysis of the degree of control exercised by the federal government over the individual recipients of incentives. Section $170(a)(1)$ provides that charitable contributions can be deducted only "if verified under regulations prescribed by the Secretary or his delegate." Those scholars who suggest that this section is not a source or regulatory control ${ }^{234}$ cannot dispute that there is an explicit requirement in section $170(a)(1)$ that a contribution be verified. It could be argued that this requirement is seldom invoked, and thus serves to exert little operative control. But the Supreme Court in Burton cautioned against such an argument: "[N]o State may effectively abdicate its responsibilities [under the Fourteenth Amendment] by either ignoring them or by merely failing to discharge them whatever the motive may be." 235

An income tax exemption under section 510(a) is similarly unavailable to an organization unless its tax exempt status has been established by the Internal Revenue Service, ${ }^{236}$ or it has notified. the Service that it believes itself qualified for exemption. ${ }^{237}$ Furthermore, if an organization fails to give notification of "material changes in its character, purposes or methods of operation," 238 the Service may revoke its determination letter retroactively. Commissioner Thrower recognized this coercive power over charitable organizations: "We know that our denial or exemption, or even our refusal to rule on the organization's qualifications, may doom the organization." 239

The Tax Reform Act of $1969^{240}$ further tightened the government's grip on exempt organizations. As a result of the

${ }^{234}$ Bittker and Kaufman underplay the regulatory role of the Internal Revenue Service under $\$ 170(a)(1)$ by contending that "a ruling or determination letter . . . is not a prerequisite to deductibility," and that deductibility "can be established after the fact by evidence that the organization met the standards of' \$170. Taxes and Civil Rights, supra note 7 , at 72 .

$235^{\circ} 365$ U.S. at 725 .

${ }^{236}$ Treas. Reg. § 1.6033-1(c) (1971). See Eliasberg, supra note 227, at 359; Sugarman, Current Legislative Changes in the Tax Treatment of Charitable Foundations: The Tax Reform Act of 1969,22 U. So. CAL. 1970 TAX INST. 547, 585.

${ }_{237}$ Treas. Reg. § 1.6033-2(c) (1971). See Koch, Reporting requirements for private foundations spelled out in final regs, $35 \mathrm{~J}$. TAXATION 304, 305 (1971).

${ }^{238} I d$. 305.

${ }^{239}$ Thrower, supra note 226 , at 168.

${ }^{240}$ Pub. L. No. 91-172, cited in McGlotten v. Connally, 338 F. Supp. 448, 457 n.48 (D.D.C. 1972). 
new legislation, fraternal orders are no longer absolved of the general requirement of section 501(a) that organizations file annual information returns, ${ }^{241}$ which must include, inter alia, the names and addresses of all substantial contributors, directors, trustees and highly compensated employees. In addition to broadening the disclosure requirements to include fraternal orders, the Tax Reform Act of 1969 enlarged the scope of information required in these annual reports, ${ }^{242}$ and instituted a new penalty system for failure to file. ${ }^{243}$ Kenneth Eliasberg noted that these new disclosure provisions are indicative of an increasingly aggressive stance on the part of Congress in exerting regulatory power over tax incentives:

[I]t is the new procedures-returns, reporting requirements and disclosure - that makes the Act a noteworthy legislative effort, for it indicates that Congress is not only concerned with the conduct at which the substantives [sic] rules are aimed, but, more significantly, that it has given the Internal Revenue Service the tools with which to more readily discover improprieties. ${ }^{244}$

And the administrative approach followed with respect to private segregated schools-defining the word "charitable" as used in the Code to exclude segregated schools-demonstrates a large untapped reservoir of control over the recipients of charitable tax incentives. ${ }^{245}$

The government's role in regulating charitable organizations should not be exaggerated, however. It was the lack of legislative review and administrative enforcement which prompted the present controversy over the use of tax incentives to implement social policy. But it is apparent that the federal government has begun to take a more active and assertive stance in controlling activity supported by charitable tax incentives. Although no concrete observations on the quantitative significance of charitable tax incentives upon a specific institution can be accurately made without empirical data, some general thoughts may be offered. The quantum approach suffers from inflexibility, but it may be of utility in those instances in which the other elements of state action are muddled. ${ }^{246}$ The quantitative significance of government involvement with a charitable organization which

241 Fraternal orders with incomes of less than $\$ 5,000$, however, continue to be exempt from the disclosure requirement. Treas. Reg. $\$ 1.6033$ (1971). See Hochberg \& Stein, Classification as a Private Foundation Has Many Tax Ramifications, $37 \mathrm{~J}$. TAxATion 88, 92 (1972); Koch, supra note 237 , at 304.

242 See Ellasberg, Sec. 501 (c)(3)-The Private Foundation: New Procedural Requirements and Noncompliance Penalties, 49 TAXES 87, 90 (1971); Koch, supra note 237, at 304.

${ }_{243}$ The penalty is $\$ 10$ per day up to a total of $\$ 5,000$. See Eliasberg, supra note 242 , at 93; Hochberg \& Stein, supra note 241 , at 92; Koch, supra note 237, at 305.

244 See Eliasberg, supra note 242 , at 87-88.

245 See note 175 supra.

${ }^{246}$ See text accompanying notes 85-94 supra. 
receives deductible contributions increases not only as the percentage of the organization's funds received through this avenue expands, but also as the tax bracket of the donor becomes higher. This result has been described as a government matching grant system. ${ }^{247}$ It is worthy of note that tax exempt income for fraternal orders includes both membership contributions and passive investment income, but for nonprofit clubs includes only membership contributions. ${ }^{248}$ The significance of the government involvement, through the section 501(c) exemption, in fraternal orders and nonprofit clubs may be computed by applying the otherwise applicable tax rate to the organization's tax exempt income, and calculating what percentage the resulting figure comprises of the organization's entire income. In most cases, this percentage will probably constitute a significant portion of the income of the organization in question.

There can be little doubt that neither the charitable deduction provided in section 170 (c) nor the exemptions to fraternal orders and nonprofit clubs provided in section 501(c) constitute elements of the basic minimum package of government benefits and services distributed to a wide range of recipients. ${ }^{249}$ The benefits of both are narrowly limited to organizations verified with specific regard to the activities undertaken by them. While the Court in Norwood and Nyquist remarked that a certain basic package of services provided by the government does not impose constitutional limitations on its recipients, ${ }^{250}$ the highly incentive, finely tailored and narrowly distributed benefits provided by the charitable tax incentives do not fall within this basic package.

Despite the absence of strong government approval of the activities of the recipients of charitable tax incentives, there is a significant degree of control and involvement in those activities. The advantages to be derived from the charitable tax incentives are not available on a broad scale to all private entities. This suggests that constitutional restrictions on the recipients might be appropriate, particularly if other elements of state action are present.

The application of the gov'ernment-objective nexus theory developed in the preceding section ${ }^{251}$ depends on whether it is construed broadly or narrowly. That theory subjects to constitutional scrutiny only those activities pursued by the beneficiaries of the government program for the purpose of accomplishing the objectives which the program was intended to advance. Both broad and narrow interpretations begin by looking at the legisla-

${ }^{247}$ See text accompanying note 27 supra.

${ }^{248}$ INT. REv. CODE OF 1954, §§ 501(c)(7)-(8), 512(a), 513(a). See McGlotten v. Connally, 338 F. Supp. 448, 458-59 (D.D.C. 1972).

${ }^{249}$ See notes 96-97 supra \& accompanying text.

${ }^{250}$ See text accompanying notes 96-103 supra.

${ }^{251}$ See text accompanying note 118 supra. 
tive objective. ${ }^{252}$ With respect to the charitable tax incentives being discussed, the only facet of a charitable organization's activities which would be suspect under a strict reading would be its performance of charitable duties. The membership policies of these organizations might seemingly be too remote from the purposes of the tax incentive to suggest constitutional limitations. Were the theory read more broadly to include all actions in the ordinary course of accomplishing the legislatively-favored objective the requisite nexus with membership policy would be established.

Although neither reading of the government-objective nexus theory has been accepted by the courts, the narrow reading does provide an arguable basis for distinguishing between discrimination by a charitable organization in its membership policies and the discharge of its charitable functions. ${ }^{253}$ If such a narrowly construed nexus theory is rejected as an insufficient safeguard to cherished constitutional rights, ${ }^{254}$ there can be little doubt that under any more broadly construed theory a sufficient nexus would exist between the charitable incentive and discriminatory membership policies of the recipients of those incentives. The verification or ruling by the Service is the sine qua non for charitable organizations, ${ }^{255}$ creating a strong bond between the existence of the charitable organization and the aid provided through the charitable deductions and exemption.

The effect of the countervaling vectors of privacy afforded by the Constitution ${ }^{256}$ must be evaluated in any comprehensive analysis of the constitutionality of charitable tax incentives. The most important of these in the context of charitable tax incentives is the first amendment freedom of association. The tension between this individual freedom and the equal protection guarantee might suggest that charitable organizations may discriminate in their membership policies, but not in the performance of the charitable duties which the incentive is designed to foster. The Court in Norwood denied affirmative constitutional protection to such private discrimination, at least where it is racially motivated. ${ }^{257}$ In such a case the invidious nature of the discrimination far outweighs the freedom of association. Nonetheless, it is possible that less compelling constitutional

252 For a discussion of the interpretive problems to be encountered in an analysis of the legislative intent of $\$ \S 170(\mathrm{c})$ and $501(\mathrm{c})$, see text accompanying notes 202-19 supra.

${ }_{253}$ See sources cited notes $119-22$ supra.

254 Such a theory might be accepted in most instances but discarded when an equal protection claim involving racial discrimination is in issue. For a fuller discussion of a less restrictive doctrine of state action in equal protection challenges, see text accompanying notes 158-72 supra.

${ }_{255}$ See notes 101-08 supra \& accompanying text.

${ }^{256}$ See text accompanying notes 123-41 supra.

25793 S. Ct. 2804,2813 (1973). 
claims might fail in the face of the freedom to associate as one chooses.

The charitable activity which is promoted by sections 170 (c) and $501(\mathrm{c})$ of the Internal Revenue Code is unquestionably a public function. ${ }^{258}$ The thrust of the myriad federal, state and local social welfare programs which flourish today is identical to that of the charitable tax incentives-aid to those members of society who are incapable of aiding themselves. Although at an earlier point in time it might have been debatable whether charity was properly a government function, since the advent of social welfare legislation it can hardly be argued that government is not expected to provide for those who cannot provide for themselves. Thus, it can fairly be said that charitable tax incentives and their recipients are dedicated to public uses, which counsels very strongly in favor of imposing constitutional restrictions upon those recipients in the performance of their public functions.

The final element bearing upon whether granting charitable tax incentives should activate constitutional restrictions is the nature of the constitutional claim alleged. Certainly, it is now probable that a lesser degree of government involvement is necessary to activate the equal protection guarantee than is necessary to activate either the due process guarantee or the establishment of religion clause. ${ }^{259}$ Therefore, in view of the observations made regarding the other elements of state action in charitable tax incentives, it is suggested that racial discrimination, if proven, in either the membership policies or the charitable functions of organizations verified under section $170(a)(1)$ or ruled upon pursuant to section 501 (c) is unconstitutional. Despite the seeming dichotomy between the exercisc of charitable functions and membership policies suggested by consideration of some of the elements of the constitutional framework, the invidiousness of racial discrimination and the absence of viable countervailing factors compels the conclusion that any discrimination practiced by recipients of charitable tax incentives is unconstitutional.

An establishment of religion claim against a religiously affiliated charity which is the recipient of the charitable tax incentives presently being discussed poses a slightly more difficult problem. Due to the strong countervailing first amendment freedoms of association and of religion, and the concomitantly greater degree of involvement requisite to a finding of state action, it seems unlikely that such a claim would succeed. AIthough Griffin and Nyquist have drained Walz of much of its

${ }^{258}$ See text accompanying notes $142-57$ supra.

${ }^{259}$ See text accompanying notes $158-72$ supra. 
potency in the equal protection realm ${ }^{260}$ there can be little doubt that, if it is anything but an entirely dead letter, Walz will preclude a finding of unconstitutionality in such a situation.

Tax incentives which should not transform their recipients into instrumentalities of the state include those related to income security. ${ }^{261}$ Welfare and social security programs quite clearly do not transform the actions of their recipients into state action, and incentives are economically equivalent to those programs. Few, for example, would argue that a racially bigoted welfare recipient is in violation of the Constitution; it seems inconceivable that a different result would follow as to present or future beneficiaries under private plans because an equivalent but less direct means was chosen to achieve the desired goal.

The deductibility of mortgage interest on owner-occupied homes, under section 163 , should also be constitutionally unobjectionable. Government approval and control of the recipients of this tax subsidy is minimal, and the nexus between the government objective-home ownership by individuals-and any equal protection claim is tenuous. As the role of the government at the federal, state and local levels in providing adequate housing increases, perhaps the public nature of housing will predominate and tip the scales in favor of a finding of state action, but at the present time housing for individuals remains an essentially private matter.

Another dimension is added when encouragement of private home ownership is sought through tax incentives granted to an intermediary, such as the mortgage lender. In very general terms, section 593 of the Internal Revenue Code provides a significant addition to bad debt reserves of saving and loan associations and mutual savings banks, if a stated percentage of their funds is invested in mortgages. This provides a subsidy which is a significant incentive to investment in home mortgages. ${ }^{262}$ Government regulatory control is far tighter than in the situation involving a single individual deducting his mortgage interest payments, while the effects upon society of discriminatory behavior are far more damaging. The function

260 See text accompanying notes $169-72$ supra.

261 See, e.g., INT. REv. CODE OF 1954, \$§ 105 (disability insurance benefits and sick pay exclusions), 151 (c), (d) (additional exemptions for the aged and blind), 104 (exclusions for workmen's compensation and damages received as a result of sickness or personal injury), 401-04 (specialized treatment of employee pension and profit sharing plans). All of these sections are widely available, and are arguably part of a basic minimum package of government services and benefits. The purposes to which these subsidies are devoted in the hands of their recipients are of an essentially private nature. It is incontrovertible that the degree of government control and approval of the recipients of these benefits is minimal. Therefore, there seems little doubt that these tax incentives should not impose constitutional limitations upon their recipients.

${ }_{262}$ For an interesting and comprehensive analysis of $\$ \mathbf{5 9 3}$, see D. Halperin, Federal Income Taxation of Banks, Sept. 28, 1971 (unpublished paper presented to the 64th Annual Conference on Taxation of the National Tax Association). 
served by these subsidized financial institutions-providing housing on a large scale-is far more public than the purchase of a home by a single individual; countervailing vectors of privacy are conspicuously absent. Surely these institutions should be bound by constitutional restrictions at least in the performance of those objectives which the legislature sought to advance through the debt reserve incentive: granting home mortgage loans. In those instances in which the claim is one of invidious racial discrimination, they should be bound by constitutional limitations in their hiring policies as well.

One final example of a tax incentive which should activate constitutional restrictions is section $167(\mathrm{k})$ of the Internal Revenue Code, which provides accelerated five-year amortization of expenditures for rehabilitation of low income rental housing. This seems closely analogous to the excess bad debt reserve for financial institutions just discussed. Most of the same factors are operative, and the same result should be achieved.

\section{Conclusion}

Tax incentives are government subsidies to private conduct which are economically functionally equivalent to legislative provisions calculated to induce economic or social behavior in the private sector. As such, tax incentives should be subject to the same constitutional limitations which have traditionally been imposed on direct government involvement with private activity, including direct grants, loans and interest subsidies.

The task of determining whether a particular tax provision was designed to promote social or economic behavior, or to serve as part of a normative neutral tax structure or as an administrative convenience, is not simple. The legislative intent underlying tax provisions is often obscure, but other considerations, such as the arguments of proponents of the provision, retention of the provision in the face of criticism, or the opinions of tax scholars, may be employed to aid in characterization of the provision. These profound definitional difficulties should not thwart the application of constitutional restrictions to the economic subsidies conferred by those tax provisions which are unquestionably incentives to economic or social behavior.

This Comment has attempted to outline a theoretical framework sufficient to analyze the constitutionality of tax incentives and other government subsidies. Among the elements of government involvement with private activity which are considered are: the nature and degree of government involvement with the otherwise private entity; the nexus between the government involvement and the challenged private activity; the 
nature of the conduct engaged in by the private entity-that is, the "privateness" or the "publicness" of the conduct; and the nature of the constitutional claim-that is, whether the conduct is challenged as a violation of the equal protection guarantee, the due process guarantee or the first amendment religion guarantees.

Through the application of this analysis to tax incentives, an often-voiced assumption-that once tax incentives are viewed as government subsidies economically equivalent to direct grants, all tax incentives will impose constitutional restrictions on their beneficiaries-has been found wanting. Just as courts have frequently declined to place constitutional restrictions on activities undertaken by otherwise private entities receiving direct government grants, they will conclude that not all tax incentives impose constitutional duties upon their recipients. A tax incentive, like a direct grant, might fail to activate constitutional restrictions for any of the following reasons: the absence of strict government control over private activity; the lack of a public function served by the private entity; an insufficiently direct connection between the tax incentive and the challenged activity; an inadequate percentage of government involvement in the total operating budget of the private entity; the presence of countervailing constitutional vectors of privacy; or the absence of an equal protection claim. Several provisions of the Internal Revenue Code have been examined, and deemed not to require constitutional scrutiny. Although the application of constitutional restrictions to tax incentives must be approached cautiously, the judiciary should take definite steps to ensure that tax provisions will not continue to serve as indirect vehicles for "nonobvious involvement of the State in private conduct." 